\title{
Карбонатитоподобная порода дайки из кимберлитовой трубки Айхал, сравнение с карбонатитами участка Номохтоох (Прианабарье)
}

Костровицкий С. И., Яковлев Д. А., Суворова Л. Ф., Демонтерова Е. И.

\begin{abstract}
Аннотация
В алмазоносной трубке Айхал из Алакит-Мархинского поля Якутской кимберлитовой провинции (ЯКП), обнаружена дайка, представленная породой, по составу имеющая сходство с карбонатитами. Мелкозернистая порода, существенно карбонатного состава (доломит, кальцит), насыщенная тонкопластинчатым флогопитом содержит типичные для карбонатитов минералы монацит, бадделеит, пирохлор. По высокому содержанию и распределению некогерентных элементов порода заметным образом отличается от кимберлитов и соответствует переходной разновидности от кимберлитов к карбонатитам. Уровень концентрации некогерентных элементов в породе из дайки трубки Айхал значительно ниже (в 3-5 раз), чем в карбонатитовых брекчиях, выполняющих трубки Староречинского кимберлитового поля ЯКП (участок Номохтоох).

Приведено сравнение составов акцессорных редкоэлементных минералов из породы дайки трубки Айхал и карбонатитовых брекчий Номохтоооха. Предполагается, что высокая концентрация некогерентных элементов в карбонатитоподобной породе, обусловившая кристаллизацию акцессорных минералов, обязана процессам дифференциации кимберлитового расплава-флюида, а повышенные изотопные отношения Sr указывают на преобразование породы гидротермальнометасоматическими процессами. Полученные данные о составе карбонатитоподобной породы не могут служить аргументом наличия генетической связи между кимберлитами трубки Айхал и классическими карбонатитами. Для северных полей ЯКП вопрос генетической связи кимберлитов и карбонатитов остается открытым.
\end{abstract}

\section{Ключевые слова:}

кимберлит, карбонатит, бадделеит, пирохлор, монацит, редкоэлементный состав, Айхал, Номохтоох 
3 КАРБОНАТИТАМИ УЧАСТКА НОМОХТООХ (ПРИАНАБАРЬЕ)

4 Костровицкий ${ }^{1,2}$ С.И., Яковлев ${ }^{1,3}$ Д.А., Суворова ${ }^{1}$ Л.Ф., Демонтерова ${ }^{2}$ Е.И.

$5^{1}$ Институт геохимии СО РАН, Иркутск, serkost@igc.irk.ru

$6^{2}$ Институт земной коры СО РАН, Иркутск

$7^{3}$ Иркутский Государственный Университет, Иркутск

8

9 "calcite kimberlites are small-volume late-forming differentiates that are not related to 10other carbonatites or their parental magmas.” 14карбонатитовыми породами широко обсуждается в литературе (Ковальский и др., 151969; Мальков, 1975; Лапин, 1986; Boctor, Boyd, 1981; Eckerman, 1967; Dawson, 16Hawthorne, 1973; Mitchell, 1979, 1986, 2007; Agashev et al., 2008; Фролов и др., 2010; 17Safonov et al., 2011; Tappe et al., 2013). Кимберлиты принадлежат семейству 18вулканических ультраосновных пород существенно оливинового состава, насыщенных 19летучими, в основном, $\mathrm{CO}_{2}$ (Mitchell, 1986). Карбонатиты представляют собой 20интрузивные и экструзивные породы, входящие в состав сложных интрузивных 21комплексов вместе с ультраосновными и щелочными породами, сложенные более чем на 2250 модальных \% карбонатами (Геол. Словарь, 1978, Bell, 1989). Карбонатиты содержат 23редкометальную минерализацию и отличаются исключительно высокой концентрацией 24некогерентных элементов (Hoernle et al., 2002; Ani1 \& Sarapää, 2013; Trofanenko et al., 252014; Moore et al., 2015; Hutchinson, 2016; Edahbi et al., 2018). Кимберлитовые и 26карбонатитовые проявления вулканизма в пределах Сибирской платформы 27пространственно разделены - первые тяготеют к центральным областям, а вторые - к 28краевым.

29 Хотя кимберлиты относятся к ультраосновным породам, но обязательное 30присутствие в них карбонатной составляющей (преимущественным образом 31представленной кальцитом), относительно высокая концентрация некогерентных з2элементов, являются аргументами существования определенного их сходства с 
3зкарбонатитами. Содержание карбонатной составляющей в якутских кимберлитах 34варьирует в широком диапазоне (от 5-10 до 80-90%, в среднем составляя 23.6 \% 35(Костровицкий, 1986, Табл. 51). Высокое содержание $\mathrm{CaCO}_{3}$ в кимберлитах отдельных 36кимберлитовых тел явилось основанием для ряда исследователей использовать для них 37термины «кальцитовый кимберлит» или «карбонатитовый кимберлит» (Mitchell, 1970; 38Skinner, Clement, 1979; Мальков, 1975). Представления о происхождении карбонатной 39компоненты, ее роли в происхождении кимберлитов существенно менялись со 40временем - от непризнания ее магматической природы (Бобриевич и др., 1964; 41Ковальский, 1963; Милашев, 1974) до заключения о ее ключевом значении в 42формировании кимберлитовых пород (Russell et al., 2012). Ряд исследователей называет 43карбонатную компоненту карбонатитовой (Лапин, Маршинцев, 1964; Agashev et al., 442008; Safonov et al., 2011; Weiss et al., 2009; Kamenetsky et al., 2015).

45 В высокоалмазоносной трубке-месторождении Айхал нами обнаружена дайка, 46выполненная породой существенно карбонатного состава (рис. 1). Высокий уровень 47некогерентных элементов и наличие таких акцессорных минералов, как монацит, 48бадделеит и пирохлор указывает на возможную принадлежность данной породы к 49карбонатитам. Задачами настоящей статьи явились - дать описание состава этой породы, 50провести сравнение ее состава с типичными кимберлитами и карбонатитами, обсудить 51вопросы, имеется ли генетическая связь между кимберлитовыми и карбонатитовыми 52породами и можно ли называть карбонатную составляющую кимберлитов 53карбонатитовой составляющей? В качестве типичной карбонатитовой породы нами 54взяты карбонатитовые брекчии, выполняющие трубки участка Номохтоох 55Староречинского кимберлитового поля (Прианабарье), описанные в ряде публикаций 56(Марщинцев,1974; Чернышева, Костровицкий, 1981; Костровицкий и др., 2007). 57Пространственное совмещение этих трубок с кимберлитовыми трубками, уровень их 58изученности обусловили приоритетность этого выбора. Дополнительно нами изучен 59химический состав кальцита и доломита (табл. 1s), флогопита (табл. 2s), монацита (табл. 607s) сульфидов (табл. 4s), а также микроэлементный состав бадделеита (табл. 5s, 8s), 61пирохлора (табл. 5, 6) и апатита (табл. 3s, 6s) из этих трубок.

62 В статье использована следующая аббревиатура названий минералов (Whitney and 63Evans, 2010): srp - серпентин, phl - флогопит, cal - кальцит, dol - доломит, ар - апатит, spl 64шпинель, mag - магнетит, py - пирит, prt - пирротин, ptl - петландит, mnz - монацит, bdy 65бадделеит и пирохлор - pcl.

\section{6 Общие сведения о трубке Айхал}


67 Детальное описание геологического строения трубки Айхал дано в публикациях 68А.Д. Харькива и др. (1995, 1997, 1998). До карьерной отработки трубка представляла 69собой крутопадающее тело дайково-трубочной формы СВ простирания (азимут 63), 70протяженностью на поверхности по длинной оси 510 м при ширине 50-120 м. С 71поверхности трубка была почти полностью перекрыта трапповым силлом. Соотношение 72длиной к короткой оси трубки изменяется от 6:1 на поверхности до 29:1 на глубине 240 м 73(Харькив и др., 1998). Трубка Айхал является примером многофазного трехканального 74тела, которое на поверхности представляло собой единое тело, глубже на отметках +374 75+100 м разделено перемычкой карбонатных пород на два рудных тела, а еще глубже на 76отметке +50 м снова разделяется на 2 тела: юго-западное и северо-восточное. 77Карьерными работами установлено участие в строении трубки четырех дотрубочных 78даек мощностью от 0.25 до 2-3 м. (Харькив, 1975). Хотя возраст формирования 79непосредственно трубки Айхал не определялся (из-за отсутствия перовскитов и 80цирконов в кимберлитах), но по аналогии с возрастами всех трубочных тел южных 81алмазоносных полей ЯКП, в том числе, Алакит-Мархинского поля, в котором трубка 82расположена, ее возраст принимается, как девон-карбоновый.

83 Существуют разные взгляды на внутреннее строение трубки Айхал. По А.Д. 84Харькиву и др. (1997), в сложении трубки приняли участие туфы, переотложенные 85осадочно-вулканогенные породы и кимберлитовые брекчии трех фаз внедрения. Ряд 86исследователей (Владимиров и др., 1981) наряду с туфами и кимберлитовыми брекчиями 87выделили также и порфировые кимберлиты (когерентный кимберлит) массивной 88текстуры. Когерентный кимберлит слагает отдельные тела в виде линз, апофиз в 89пределах развития кимберлитовых брекчий, а иногда и во вмещающих породах, 90включения типа «кимберлит в кимберлите» в туфовых разновидностях. 91Субгоризонтальные элементы залегания тел ПК являются характерной особенностью для 92Ю3 половины трубки. Вулканокластические кимберлиты представляют собой серую, 93сильно карбонатизированную мелкообломочную породу, в разной степени (5-20\%) 94насыщенную ксеногенным материалом вмещающих пород. Иногда отмечается сортировка 95обломочного материала по крупности. В туфовидных кимберлитах встречаются округлые 96включения более ранней фазы внедрения порфирового кимберлита. Все разновидности 97кимберлита, слагающие трубку Айхал характеризуется относительно высокой степенью 98карбонатизации.

99 Дайка кимберлита карбонатитоподобного состава мощностью до 20 см была 100обнаружена в Ю3 части трубки ориентировочно на гл. 200 м. от поверхности при 
101подземной ее отработке. Порода дайки srp-phl-cal-dol состава, имеющая тонкозернистую 102структуру, афировую текстуру (рис. 2), практически лишена макро-, микрокрист ol (и 103псевдоморфоз вторичных минералов по оl) и содержит акцессорные ap, mnz, pcl, bdy, 104бетафит и сульфиды. Модальный минеральный состав породы - 5\% srp, 10\% cal, 35\% phl, 10550\% dol. Как правило, зерна доломита и флогопита характеризуются идиоморфной и 106субидиоморфной формой, кальцит и серпентин - ксеноморфной.

\section{7 Общие сведения о карбонатитовых трубках Прианабарья}

108 На северо-западе Якутской провинции в пределах Староречинского (участок 109Номхтооох) и Орто-Ыаргынского полей, Прианабарье наряду с кимберлитовыми 110трубками были обнаружены трубки, в которых доминирует карбонатитовый материал. На 111относительно небольшой площади участка Номхтооох (не >16 км²) вскрыто шурфами 112более 50 тел, сложенных карбонатитовыми и кимберлитовыми брекчиями. Детальное 113петрографическое описание пород из этих трубок приведено в монографиях В.К. 114Маршинцева (1974), Ковальского и др. (1969), Бородина и др. (1976), а также в ряде 115статей (Чернышева, Костровицкий, 1981, 1998). U-Pb возраст кимберлитовых и 116карбонатитовых трубок Прианабарья, в том числе, из участка Номохтоох, определенный 117по перовскитам и цирконам, соответствует верхней юре и варьирует в интервале 150-161 118(Barton et al, 1995; Griffin et al, 1999; Sun et al, 2014, 2018).

119 Нами был изучен материал из трубок участка Номохтоох (рис. 1), в котором на 120площади 30-35 км² было обнаружено 46 карбонатитовых и 7 кимберлитовых трубок 1210круглой, овальной, неправильной формы, большинство из которых по максимальному 122размеру не превышает 100-150 м. (Маршинцев, 1974). Вмещающими породами трубок 123участка Номохтоох являются верхнепротерозойские и кембрийские терригенно124карбонатные отложения. Карбонатитовые брекчии представляют собой породы серого, 125буровато-серого цвета, насыщенные ксеногенным материалом вмещающих пород 126(известняки, реже песчаники, отдельные ксенолиты пород кристаллического 127фундамента). Основная масса карбонатитовой брекчии представлена, в основном, 128тонкозернистым cal (до 70-85\%) и dol (7-28\%), содержащего зерна ap (1-5\%), phl (0,151294.4\%), mag (0.1-3.7\%) (Маршинцев, 1974). В качестве акцессорных минералов находятся 130bdy, pcl, ilm, циркон, колумбит, торит. Данные минералы характеризуются 131преимущественным образом обломочной угловатой формой, реже - субидиоморфной 132(рис. 3g, 3h, 7s-supplementary). Доломит также чаще обнаруживается в виде мелких 13зугловатых обломков, погруженных в криптокристаллический cal. По минеральному 
134составу карбонатитовые брекчии участка Номохтоох относятся к доломит-кальцитовому 135типу карбонатитов.

\section{6 Методика аналитических работ}

137 Аналитические работы по определению петрогенных оксидов в образцах методом 138РФА, микроэлементов методом ICP-MS и электронно-зондовые исследования 139проведены в ЦКП «Изотопно-геохимических исследований» Института геохимии им. 140А.П. Виноградова СО РАН, г. Иркутск.

141 Содержание петрогенных оксидов было определено методом РФА на спектрометре 142СРМ-25 (предел обнаружения 10 ppm). Измерения выполнены при напряжении 30 кВ, 143ток 40 мА. Рентгеновская трубка с Rh-анодом. Образцы гомогенизировали с помощью 144сплавления с флюсом - метаборатом лития (LiBO2) в индукционной печи в тиглях из 145стеклоуглерода при температуре 1100 град. С. Соотношение проба:флюс - 1:2. Перед 146проведением пробоподготовки определяются потери летучих при температуре 950 град. 147Для калибровки использовали стандартные образцы горных пород - СГД-1А (габбро), 148СИ-2 (Карбонатит), JB-1 (базальт), JP-1 (перидотит) (Япония).

149 Концентрации редких элементов в породах определялись методом масс150спектрометрии с индуктивно-связанной плазмой (ICP-MS) на спектрометре Elan 6100 151DRS в Институте геохимии CO РАН. Аналитики: Н. Пахомова. Использовано кислотное 152разложение проб. Точность многократно повторяемых анализов на стандарте составляла $153<5 \%$ для Sr, La, Ce, Nd, Sm, Tb, Ho, Er, Yb, и 5-15\% для Y, Zr, Pr, Eu, Gd, Dy, Tm, Lu, Hf. 154Пределы обнаружения - 0.01-0,03 ppm. Содержание $\mathrm{Na}, \mathrm{K}, \mathrm{Li}, \mathrm{Rb}, \mathrm{Cs}$ определялось 155методом пламенной фотометрии (предел обнаружения $1 \mathrm{ppm}$ ). Для определения $\mathrm{Ni}, \mathrm{Cr}$, 156Cr, V, Zn, Cu был использован атомно-адсорбционный метод (предел обнаружения - 10 157ppm).

158 Количественный элементный анализ минералов-спутников алмаза, минералов 159основной массы кимберлитов проведен на электронно-зондовом микроанализаторе 160Superprobe JXA-8200 фирмы Jeol с пятью спектрометрами с волновой дисперсией при 161следующих аналитических условиях: ускоряющее напряжение 20кВ, ток пучка 162электронов 20нА, время счета импульсов 10 с на пике и фона - по 5 с каждой стороны от 163линии (аналитик Суворова Л.Ф.). Морфология, зональность и количественное 164соотношение минералов в кимберлитах изучены на растровом электронном микроскопе 165по изображениям в обратно-рассеянных электронах (BSE) при различных увеличениях. 

167JXA-8200, Jeol. Ltd. (Япония) с использованием спектрометров с волновой дисперсией и 168фирменного матобеспечения (аналитик Суворова Л.Ф.). Анализируемым образцами 169служили полированные аншлифы породы. Условия возбуждения и регистрации 170аналитических сигналов следующие: ускоряющее напряжение 20 кВ, ток пучка 171электронов 20 нА, его диаметр 1-10 мкм в зависимости от анализируемого объекта, время 172счета импульсов на пике линии 10 с, фон измерялся с двух сторон от пика линии - по 5 с. 173Коррекция аналитического сигнала на матричные эффекты осуществлялась ZAF174методом. Определялись следующие элементы: F, Na, Mg, Al, Si, P, S, Cl, K, Ca, Ti, Mn, Fe, 175Ni, Cu, Sr, Ba, Nb, La, Ce, Nd, Pr, Zr, Y, Th. Пределы обнаружения - 0,05-0,1\% мас. В 176качестве образцов сравнения использовались природные и синтетические минералы, 177аттестованные как лабораторные образцы сравнения в Институте геологии и 178минералогии СО РАН, г. Новосибирск. При измерении состава очень мелких зерен 179бетафита $(<3 \mathrm{~m} \mu)$ произошел захват вмещающей матрицы, и поэтому пересчитанный 180анализ следует считать полуколичественным. Морфология, зональность и 181количественное соотношение минералов в кимберлитах с различными структурными 182особенностями изучены на растровом электронном микроскопе по изображениям в 183обратно-рассеянных электронах (BSE) при различных увеличениях.

184 Изотопные исследования $\mathrm{Sr}$ и $\mathrm{Nd}$ выполнены в Центре коллективного пользования 185Института земной коры СО РАН “Геодинамика и геохронология”. Изотопные отношения $186 \mathrm{Nd}, \mathrm{Sr},{ }^{147} \mathrm{Sm} /{ }^{144} \mathrm{Nd}$ и ${ }^{87} \mathrm{Rb} /{ }^{86} \mathrm{Sr}$ определены с добавлением трассеров ${ }^{149} \mathrm{Sm}-{ }^{150} \mathrm{Nd}{ }^{84} \mathrm{Sr}-{ }^{85} \mathrm{Rb}$ 187к истертому образцу. Выделение $\mathrm{Sr}, \mathrm{Rb}$ и Р3Э из растворенных в смеси кислот навесок 188образцов проводилось на катионообменных колонках объемом 2 мл заполненных смолой 189BioRed AG 50Wx8-mesh. Очистка стронция проводилась на этих же колонках во вторую 190ступень работы. Разделение Sm от Nd проводилось на колонках, заполненных смолой 191LnSpec (Pin, Zalduegui, 1997). Изотопные отношения Sr, Rb, Nd и Sm измерялись на 192многоколлекторном твердофазном масс-спектрометре Finnigan MAT262. В период 193измерений значения изотопного стандарта стронция NBS 987 составили ${ }^{87} \mathrm{Sr} /{ }^{86} \mathrm{Sr}=$ 1940.7102680.000011, JNd-1 ${ }^{143} \mathrm{Nd} /{ }^{144} \mathrm{Nd}=0.5120870 .000005$.

\section{5 Химический и микроэлементный состав}

196 В табл. 1 и 2 приведены составы кимберлитов из трубки Айхал (в том числе, из 197карбонатитоподобной дайки), а также карбонатитовых брекчий и вулканокластического 198кимберлита из участка Номохтоох Староречинского поля. Соответствующие графики (рис. 1994) демонстрируют особенности составов из дайки по сравнению с составом кимберлитов 
200из трубки Айхал и карбонатитовых брекчий из участка Номохтоох. В целях 201представительности информации мы использовали в графиках наряду с собственными и 202литературные данные по составу кимберлитов из трубки Айхал (Илупин и др., 1978) и 203карбонатитовых брекчий из участка Номохтоох (Маршинцев, 1974). Кимберлиты из 204трубки Айхал относятся к высоко-Mg петрохимическому типу с относительно низким 205содержанием $\mathrm{FeO}, \mathrm{TiO}_{2}$ и характеризуются значительной изменчивостью состава, что 206связано с широкой вариацией содержания карбонатной составляющей, представленной, в 207oсновном, cal (20-70\% $\left.\mathrm{CaCO}_{3}\right)$. Карбонатитоподобная порода из дайки отличается низким 208содержанием $\mathrm{SiO}_{2}$ (10.7-13.6\%), повышенным содержанием $\mathrm{K}_{2} \mathrm{O}$ (1.5-2.2\%) и $\mathrm{P}_{2} \mathrm{O}_{5}(0,5-$ 2091,0\%) и высоким содержанием карбонатной компоненты, представленной cal и 210преимущественно dol (до 80\% $\mathrm{CaCO}_{3}+\mathrm{CaMgCO}_{3}$ ). Карбонатитовая брекчия из участка 211Номохтоох характеризуется (Маршинцев, 1974; табл. 31, среднее из 36 анализов) низким 212содержанием $\mathrm{SiO}_{2}$ (4.3-19.2, среднее 12.2\%) и высоким содержанием карбонатной 213составляющей $\left(\mathrm{CaO}+\mathrm{CO}_{2}\right.$ варьирует в пределах 24.2-69.4\%; среднее 55.3\%) и отличается 2140т кимберлитов трубки Айхал относительно высоким содержанием $\mathrm{FeO}_{\text {total }}$ (среднее 9.96\%) 215и низким MgO (2.4-13.4\%; среднее 9.66\%). Полученные нами данные по составу 216карбонатитовых брекчий из участка Номохтоох (табл. 1) согласуются с литературными, 217приведенными выше.

218 По уровню содержания некогерентных элементов карбонатитоподобная порода из 219дайки трубки Айхал (табл. 2, рис. 5) значительно (на полпорядка) превосходит 220кимберлиты из этой же трубки и занимает на спайдергаммах промежуточное положение 221между кимберлитами трубки Айхал и карбонатитовыми брекчиями участка Номохтоох. 2223аметным образом отличаются и значения показательных отношений некогерентных 223элементов ( $\mathrm{La} / \mathrm{Yb}, \mathrm{La} / \mathrm{Nb}, \mathrm{Nb} / \mathrm{Ta}, \mathrm{Zr} / \mathrm{Hf}, \mathrm{Pb} / \mathrm{Ce})$, рассчитанные для кимберлитов, 224карбонатитоподобной породы из трубки Айхал и карбонатитовых брекчий из участка 225Номохтоох (табл. 2, рис. 8s). Заметим, что кимберлитовая брекчия из участка Номохтоох 226(проба № 90-67, трубка Джо-северная) как по уровню содержания некогерентных 227элементов, так и по значению показательных отношений (табл. 2) не отличается от 228типичных кимберлитов.

\section{Sr-Nd изотопный состав}

230 Нами изучена изотопная Sr-Nd систематика для двух образцов карбонатитоподобной 231породы из дайки Айхал. При анализе полученных данных мы использовали полученные 232ранее нами данные по изотопным характеристикам кимберлитов из трубки Айхал и 233карбонатитовых брекчий из участка Номохтоох (Костровицкий и др., 2007). Изотопные 
234характеристики кимберлитов из трубки Айхал и карбонатитовых брекчий в координатах $235\left({ }^{87} \mathrm{Sr} /{ }^{86} \mathrm{Sr}\right)_{0}-\varepsilon \mathrm{Nd}$ (рис. 6) отвечают таковым для изученных ранее (Smith, 1983; Mitchell, 1986; 236Tainton, McKenzie, 1994) кимберлитов типа 1 из разных провинций Мира, - все 4 точки 237изотопных составов попадают в область слабо истощенной мантии. Расположение 238фигуративных точек Sr-Nd состава для карбонатитоподобной породы из дайки трубки 239Айхал на графике смещено в сторону осадочно-морского репера; в то время как значение $240 \varepsilon \mathrm{Nd}$, также, как и для кимберлита из трубки (проба 01-361), попадает в область слабо 241истощенной мантии. Смещение изотопного состава Sr обусловлено проявлением широкого 242по масштабу наложенного процесса карбонатизации, характерного не только для трубки 243Айхал, но и для всех кимберлитовых полей ЯКП (Костровицкий и др., 2007).

244

\section{5 Состав минералов}

246 Карбонатитоподобная жила сложена породой srp-cal-phl-dol состава. Акцессорная 247минерализация представлена ap, spl, mnz, bdy, pcl и сульфидами. В качестве включения в 248макрокристе phl встречено зерно бетафита (высоко-Ті минерал из группы пирохлора, 2490богащенный REE). Состав основных породообразующих минералов из 250карбонатитоподобной жилы трубки Айхал приведен в supplementary, табл. 1s, 2s, 3s.

251 Доломит образует зерна идиоморфной и субидиоморфной формы размером от 25210x10 до до $200 \mathrm{m \mu}$ ), иногда агрегаты зерен (рис. За). Содержание SrO в dol широко 253варьирует от 0.01 до $0.17 \%$, что свидетельствует о его кристаллизации в относительно 254широком температурном интервале. cal неравномерно распределен в основной массе 255породы, иногда образует каймы вокруг кристаллов phl. Редкие идиоморфные кристаллы 256cal характеризуются высокой концентрацией $\operatorname{SrO}$ (до 0.81\%), в то время как в 257 доминирующем cal содержание $\mathrm{SrO}<0.1 \%$. Один из самых распространенных минералов 258карбонатитоподобной породы phl образует в основной массе идиоморфные и 259субидиоморфные кристаллы размером от 30х20 до 200x80 m 260широкой вариацией таких оксидов, как $\mathrm{TiO}_{2}$ (0.7-1.8\%), $\mathrm{FeO}$ (3.0-14.1\%), $\mathrm{BaO}$ (0.2-2.6\%). 261Широкий диапазон содержания оксидов, скорее всего, связан с крайней 262неоднородностью состава кристаллизующегося расплава.

263 Апатит образует в матрице существенно доломитового состава неравномерно 264рассеянные идиоморфные призматические кристаллы размером от 10х5 до 40х10 mн (рис. 2653b), иногда сростки и двойники кристаллов. Из акцессорных минералов карбонатитовой 266ассоциации в трубке Айхал заметное распространение получил только mnz размером 1-5 


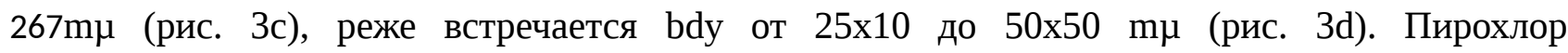
268(Na,Ca,TR,U,Th,Zr $)_{2}(\mathrm{Nb}, \mathrm{Ta}, \mathrm{Ti})_{2} \mathrm{O}_{6}(\mathrm{~F}, \mathrm{OH}) \quad$ образует $\quad$ кристаллы $\quad$ размером $7 \mathrm{x} 5 \quad \mathrm{~m} \mu$ и 269обнаруживается чрезвычайно редко (рис. Зе). В кристалле phl обнаружено включение 270бетафита ((Ca,Na,U) $)_{2}(\mathrm{Ti}, \mathrm{Nb}, \mathrm{Ta})_{2} \mathrm{O}_{6}(\mathrm{OH})$ - минерал группы pcl) округлой формы размером 2712x2 mu (рис. 3f). По сравнению с pcl бетафит обогащен $\mathrm{TiO}_{2}$ (до 14.2\%) и REE (до 16\%) 272(табл. 5). К сожалению, из-за малых размеров зерен корректный анализ всех 273перечисленных выше минералов осуществить не удалось. Приведенные в Табл. 5, 6, 4s, 7s 274анализы для mnz, pcl и бетафита включают в себя оксиды (например, $\mathrm{SiO}_{2}, \mathrm{Al}_{2} \mathrm{O}_{3}, \mathrm{CaO}$, 275MgO), которые частично, или полностью принадлежат матрице (состоящей из cal, phl, srp), 276окружающей эти минералы. Барит встречается в виде редких микрокристаллов 277идиоморфной формы таблитчатой формы размером от 2-3 до 30х15 mu (рис. За).

278 Сульфиды представлены микрозернами пирита, петландита и халькопирита (рис. За, 2793f) размером от 1 до $15 \mathrm{m \mu}$ субидиоморфной, реже неправильной формы. Наряду с 280преимущественно рассеянным типом распределения сульфиды образуют отдельные 281скопления - микрозонки размером 100x10 mu. Сульфидная минерализация развивается в 282матрице основной массы карбонатитоподобной породы в межзерновых интерстициях 283между phl и dol. Состав сульфидов представлен в табл. 4s.

284 Типоморфные акцессорные минералы (pcl, bad и ap) были отобраны из тяжелой 285фракции карбонатитовых брекчий участка Номохтоох - из трубок Джо-южная, Джо286северная, Последняя, Аномалия 35 (рис. 3h, 3g, 7s; табл. 6s, 6, 8s). Пирохлор находится в 287виде идиоморфных, иногда округло-угловатых обломков кристаллов октаэдрической 288формы размером от 0.2 до 1.5 мм серого, буровато-серого цвета, красно-коричневого 289цвета. Бадделеит образует пластинчатые кристаллы (чаще в виде их обломков) светло290коричневого, темно-бурого цвета размером от 0.3 до 2.0 мм. Апатит представлен 291идиоморфными и субидиоморфными бесцветными кристаллами вытянутой 292призматической формы размером от 0.1 до 0.8 мм. Составы минералов оказались 293типичными для карбонатитовых пород (Динс, 1969; Капустин, 1971; Terry, 1996; Зайцев и 294др. 2012). Pcl при существенном доминировании $\mathrm{Nb}_{2} \mathrm{O}_{5}$ (66-69,9\%) содержит изоморфные 295с CaO примеси SrO (0.7-5.7\%) и REE (в основном, La и Ce - 0.4-4.0\%). Бадделеит с 95.329698.0\% $\mathrm{ZrO}_{2}$ содержит примеси $\mathrm{Nb}_{2} \mathrm{O}_{5}$ 0.5-2.7\% и $\mathrm{HfO}_{2}$ 1.3-1.8\% (табл. 8s). В макрокристах 297ар наиболее высокие изоморфные примеси образуют $\mathrm{SrO}(0.3-2.3 \%)$ и $\quad \mathrm{Ce}_{2} \mathrm{O}_{3}(0.2-0.7 \%)$. 2980собенностью кристаллов пирохлора является частая встречаемость включений апатита, 299как одиночных, так и групповых, характеризующихся разной направленностью в 300отдельных доменах кристалла апатита (рис. 3h, 3g). Включения ар в макрокристах рсl 
3010тличаются по составу высоким содержанием $\mathrm{SrO}$ (до 8.3\%) и редкоземельных элементов 302( $\mathrm{La}_{2} \mathrm{O}_{3}$ до 2\%; $\mathrm{Ce}_{2} \mathrm{O}_{3}$ до 4\%; $\mathrm{Nd}_{2} \mathrm{O}_{3}$ до 1.3\%).

303

304

305

\section{Обсуждение}

306 Р. Митчелл показал (Mitchell, 1986, 2007), что ни геологическая позиция пород, 307ни их минералогические особенности не позволяют усматривать генетическую связь 308между кимберлитами и карбонатитами. Хотя для отдельных районов Сибирской и Южно309Африканской платформ установлена тесная пространственная связь кимберлитов и 310щелочно-ультраосновных карбонатитовых комплексов, в целом для них характерна 311пространственная разобщенность (Verwoerd, 1966; Бородин и др., 1976; Лапин, 1986). С 312другой стороны, ряд исследователей (Bailey, 1993; Dalton \& Presnall, 1998) полагают, что 313генетическая связь между этими двумя карбонат-содержащими типами пород существует. 314Авторы считают, что и кимберлитовые, и карбонатитовые магмы имеют один и тот же 315мантийный источник и произошли в результате плавления $\mathrm{CO}_{2}$-содержащего гранатового 316лерцолита. Экспериментальные исследования (Gudfinnsson \& Presnall, 2005) показали 317принципиальную возможность появления составов расплава при разных Р-Т условиях, 318разных степенях плавления перидотита, которые отвечают последовательному 319становлению карбонатитового, кимберлитового, милилитового, базальтового, пикритового 320и коматиитового расплавов, находящихся в равновесии с гранатовым перидотитом.

321 Ранее был сделан вывод (Воробьев и др., 1978; Костровицкий, 1986), что и по 322содержанию щелочноземельных ( $\mathrm{Sr}, \mathrm{Ba})$ и редкоземельных элементов карбонаты из 323кимберлитов не достигают уровня, устанавливаемого для кальцитов из карбонатитов, 324хотя в отдельных случаях и приближаются к нему. Заметные различия между 325кимберлитами и карбонатитами обнаруживаются в особенностях распределения всех 326несовместимых элементов (и по уровню концентраций, и по форме кривых на 327спайдерграммах), что было продемонстрировано на примере трубочных тел, выполненных 328этими породами на севере Якутской кимберлитовой провинции (Костровицкий и др., 2007).

329 Порода, выполняющая дайку трубки Айхал, как имеющая существенно карбонатный 330состав, как содержащая акцессорные минералы mnz, bdy и pcl, соответствует 331классическим карбонатитовым породам, но по ряду геохимических параметров, в 332частности, по концентрации некогерентных элементов не достигает их уровня (рис. 5). По 
3ззсравнению с карбонатитовыми брекчиями из участка Номохтоох карбонатитоподобная 334порода из трубки Айхал отличается более низкой концентрацией REE (2090-2868 и 654833510282 г/т соответственно, табл. 2). Существенное отличие карбонатитовых брекчий участка 336Номохтоох от карбонатитоподобной породы из трубки Айхал заключается и в 337относительно высоком содержании в брекчиях $\mathrm{FeO}_{\text {total }}$ (среднее для брекчий - 9.96\%, для 338породы из трубки Айхал - 3.6\%) и низком содержании $\mathrm{MgO}$ (среднее для брекчий - 9.7\%, 339для породы из трубки Айхал - 20\%). Именно поэтому породу, выполняющую дайку 340трубки Айхал, мы называем карбонатитоподобной, хотя по формальным признакам 341подобные породы иногда относят к карбонатитам (Gaspar and Wyllie 1984).

342 Природа первичных кимберлитовых расплавов до сих пор является предметом 343дискуссий. Многие исследователи считают, что кимберлиты с афанитовой текстурой, 344содержащие повышенное содержание $\mathrm{CaCO}_{3}$, характеризуются составами наиболее 345близкими к первичным кимберлитовым расплавам (Shee, 1986; Edgar et al., 1988; Edgar \& 346Charbonneau, 1993; Price et al., 2000; Kopylova et al., 2007). Карбонатитоподобная порода 347из трубки Айхал, имеющая афанитовую текстуру, практически не содержит макрокрист 348ol (или псевдоморфоз по оливину) и поэтому, если следовать логике перечисленных 349выше авторов, может претендовать на идеальную модель первичного кимберлитового 350расплава. Однако, изотопные Sr-Nd параметры (табл. 3, 4) породы явно свидетельствуют 3510 том, что в ее формировании заметную роль сыграли вторичные гидротермально352метасоматические процессы преобразования.

353 Описанные выше минералы (bdy, pcl, бетафит), встреченные в дайке, не характерны 354для кимберлитовых пород, но являются обычными акцессорными минералами в 355карбонатитах (Капустин, 1971). Впрочем, bdy редко, но обнаруживается в кимберлитовых 356породах с высоким содержанием карбонатной компоненты, например, в силле 357Бенфонтейна, Ю. Африка (Scatena-Wachel and Jones, 1984) в трубке Mbuji-Мауi, Конго 358(Pivin et al., 2013). Мы предполагаем, что образование карбонатитоподобной породы 359произошло на заключительном этапе процесса дифференциации кимберлитового 360расплава-флюида с отделившиеся фазой существенно карбонатного состава при 361становлении трубки Айхал (возможно, в результате процессов гравитационной отсадки 362барофильных минералов). Относительно высокая концентрация некогерентных элементов 363по сравнению с кимберлитами в остаточном флюиде предопределила кристаллизацию в 364дайке таких типоморфных для карбонатитовых пород минералов, как mnz, bdy, pcl и 365бетафит. K подобным выводам пришли (Smith et al, 2013), описав карбонатитовую 
366интрузию в алмазоносной кимберлит-лампрофировой трубке Khaderpet (Dharwar Craton, 367India) как поздний продукт фракционирования ультраосновной магмы.

368 Все трубочные тела участка Номохтоох, представленные, как к карбонатитовыми, так 369и кимберлитовыми брекчиями (Маршинцев, 1974), содержат типичную карбонатитовую 370акцессорную минерализацию. Кимберлитовые брекчии отличаются от карбонатитовых: 1) 371более высоким содержанием MgO в первых (Обр. 90-67, Трубка Джо-северная), 372обусловленным их насыщенностью макрокристами оливина (псевдоморфоз srp по ol), 2) 37зболее низким содержанием карбонатной компоненты и акцессорных типоморфных 374карбонатитовых минералов, 3) значительно более низкой концентрацией несовместимых 375элементов. Обсуждая вопрос существования генетической связи между кимберлитами и 376карбонатитами, следует отметить наличие четких различий в особенностях локализации 377этих вулканитов в южной алмазоносной и северной с убогой алмазоносностью 378субпровинциях ЯКП. Если в южной части ЯКП типичные карбонатитовые тела (массивы) 3790тсутствуют, то северная часть, можно сказать, изобилует ими. Кимберлитовые поля 380Прианабарья окружены с востока и запада пятнадцатью формациями ультраосновных381щелочных пород и карбонатитов (УЩК) с крупными карбонатитовыми массивами 382(Фролов и др., 2003, рис. 1.3.4. Схема размещения УЩК и кимберлитовых полей). При 383этом один из массивов - Мальджангарский находится в непосредственной близости 384Лучаканского и Берегендинского кимберлитовых полей. Предполагается (Маршинцев, 3851974; Чернышева, Костровицкий, 1981), что под кимберлитовым участком Номохтоох 386Староречинского поля находится не выходящий на поверхность карбонатитовый массив. 387Карбонатитовый материал, обнаруживаемый в трубочных телах (в том числе, и в 388кимберлитовых трубках), находится только в обломочном виде и был захвачен при 389формировании кимберлитового участка Номохтоох. О существовании карбонатитового 390массива, по мнению В.К. Маршинцева свидетельствуют также многочисленные ксенолиты 391фенитизированных кристаллических пород, обнаруживаемых в брекчиях. Наличие 392«слепых» карбонатитовых массивов, сопровождающееся формированием надинтрузивных 393трубочных структур, предполагается (Фролов и др., 2003) для многих провинций и, в 394частности, для Маймеча-Котуйской (Егоров, 1991). И таким образом, вопрос генетической 395связи между кимберлитами и карбонатитами, по-видимому, необходимо решать раздельно 396- для классических алмазоносных кимберлитов, получивших развитие в центральной 397части Сибирского кратона, и для неалмазоносных (или с убогой алмазоносностью) 398кимберлитов в северной окраине кратона. 
399 Наличие карбонатитоподобной породы (а по формальным признакам, карбонатита) в 400дайке трубки Айхал не может служить аргументом существования генетической связи 401между алмазоносными кимберлитами и карбонатитами. Во-первых, несмотря на высокую 402концентрацию некогерентных элементов в карбонатитоподобной породе, превышающую 403значения, характерные для кимберлитовых пород, она не достигает уровня, типичного для 404карбонатитовых пород (различие примерно на полпорядка). Во-вторых, обнаруженные в 405дайке минералы, типоморфные для карбонатитов, являются чрезвычайно мелкими и 406редкими акцессориями. Главное же различие заключается в источнике некогерентных 407элементов. Если для карбонатитовых пород высокая концентрация некогерентными 408элементами обусловлена первичным составом мантийного источника, то для дайки трубки 409Айхал она обязана процессам дифференциации кимберлитового расплава-флюида. И 410таким образом, обнаружение самой дайки в кимберлитовой трубке Айхал отнюдь не 4110провергает заключения большинства исследователей об отсутствии между 412алмазоносными кимберлитами и карбонатитами генетической связи.

413 Вопрос наличия генетической связи с карбонатитами для кимберлитов северных 414полей ЯКП остается открытым. Был ли у предполагаемого «слепого» карбонатитового 415массива и кимберлитовых трубок участка Номохтоох один и тот же магматический очаг? 416Учитывая пространственную близость и сходство возрастных оценок формирования 417кимберлитовых и карбонатитовых трубок для Староречинского и соседнего с ним Орто418Ыаргинского полей, выполненных U-Pb методом по перовскитам (все определения 419попадают в интервал 162-170 млн. лет, Barton et al., 1995; Griffin et al., 1999; Sun et al., 4202014), такое предположение вполне допустимо, хотя и остается дискуссионным. Остается 4210бъяснить контрастные (на порядок) различия в уровне концентрации некогерентных 422элементов, существенные отличия значений показательных отношений элементов для 423пород, выполняющих кимберлитовые и карбонатитовые трубки участка Номохтоох 424(сравнить составы по образцам № 90-67 и 78-1558, 78-1565 соответственно, табл. 2), 425которые больше согласуются с выводом о разных мантийных источниках для кимберлитов 426и карбонатитов. Следует при этом отметить, что высокие концентрации несовместимых 427элементов и, прежде всего, REE в карбонатитовых брекчиях участка Номохтоох, 428превышающие максимальные концентрации в кимберлитовых породах (Илупин и др., 4291986; Костровицкий и др., 2007) почти на порядок, являются типичными для карбонатитов 430(Hoernle et al., 2002; Ani1 \& Sarapää, 2013; Trofanenko et al., 2014; Moore et al., 2015; 431Hutchinson, 2016; Edahbi et al., 2018). 
Что касается вопроса, можно ли называть карбонатную составляющую кимберлитов 433карбонатитовой? Поскольку различия в концентрации некогерентных элементов в 434кимберлитовой составляющей и карбонатитах значительные, то, если согласиться с 435выводом об отсутствии генетической связи между породами, называть ее карбонатитовой, 436на взгляд авторов, означает вносить определенную терминологическую путаницу.

437

\section{8Заключение}

439 Сравнение химического, микроэлементного, минерального состава кимберлитов, 440карбонатитоподобной породы из трубки Айхал и карбонатитовых брекчий из трубок 441участка Номохтоох Староречинского поля позволило авторам прийти к следующим 442выводам:

443 1) Происхождение карбонатитоподобной породы из дайки трубки Айхал связано с 444 заключительным этапом процесса дифференциации кимберлитового расплава-флюида 445 при становлении трубки, с отделившиеся фазой существенно карбонатного состава 446 (возможно, в результате процесса гравитационной отсадки барофильных минералов).

447 2) Относительно высокая концентрация некогерентных элементов по сравнению с 448 кимберлитами (TR, HFSE, Sr, Ba, P) в остаточном флюиде обусловила 449 кристаллизацию в дайке трубки Айхал типоморфных для карбонатитовых пород 450 минералов (mnz, bad, pcl и бетафит).

451 3) Концентрация некогерентных элементов в карбонатитоподобной породе из дайки 452 трубки Айхал превышает таковые значения, характерные для кимберлитовых пород, 453 но не достигает уровня, типичного для карбонатитовых пород (различие примерно на 454 полпорядка).

455 4) Идиоморфная форма типоморфных для карбонатитовых брекчий участка Номохтоох 456 минералов (bdy, pcl, ap), взаимоотношения минералов друг с другом (наличие 457 включений ар в кристаллах pcl) свидетельствует о их близкой по времени 458 кристаллизации при формировании карбонатитов, подвергнутых позднее процессам 459 брекчирования.

460 5) Наличие карбонатитоподобной породы из дайки трубки Айхал не может служить 461 аргументом существования генетической связи между алмазоносными кимберлитами 462 и карбонатитами, поскольку различна природа высокой концентрации 463 некогерентными элементами. Если для карбонатитовых пород высокая концентрация 
465 источника, то для дайки трубки Айхал она обязана процессам дифференциации 466 кимберлитового расплава-флюида. И поэтому было бы неправильным называть 467 карбонатную компоненту кимберлитовых пород карбонатитовой.

468 6) Вопрос наличия генетической связи с карбонатитами для кимберлитов северных 469 полей ЯКП остается открытым.

470Благодарности: Авторы благодарны геологическому руководству АК АЛРОСА за 471предоставленные возможности проведения полевых работ на кимберлитовых трубках 472ЯКП. Авторы благодарят рецензентов О.Г. Сафронова и А.М. Агашева за 473конструктивные замечания, позволившие заметным образом улучшить содержание 474статьи и уточнить ее выводы. Исследование проведено в рамках выполнения 475государственного задания по Проекту IX.129.1.5. (№0350-2016-0030). Работа выполнена 476с использованием научного оборудования ЦКП “Изотопно-геохимических исследований” 477ИГХ СО РАН.

478

\section{9Литература}

480Бобриевич А.П., Илупин И.П., Козлов И.Т., Лебедева Л.И., Панкратов А.А., Смирнов 481Г.И., Харькив А.Д. Петрография и минералогия кимберлитовых пород Якутии / Под ред. 482В.С. Соболева. М., Недра, 1964, 192 с.

483Бородин Л.С, Лапин А.В., Пятенко И.К. Петрология и геохимия даек щелочно484ультраосновных пород и кимберлитов. Изд-во Наука. Москва. 1976. 244 с.

485Владимиров Б.М., Костровицкий СИ., Соловьева Л.В., Боткунов А.И., Фивейская Л.В., 486Егоров К.Н. Классификация кимберлитов и внутреннее строение кимберлитовых трубок. 487М.: Наука, 1981, 136 с.

488Воробьев Е.И., Костровицкий СИ., Владимиров В.М., Арсенюк Л.И., Соловьева Л.В. 489Стронций, барий и редкоземельные элементы в кальцитах из кимберлитов Якутии. 490Геохимия. 1978, № 9, с. 1343-1350.

491Геологический словарь. М.: Недра, Т. 1, 1978, 486 с.

492Динс Т. Геолого-экономическая характеристика карбонатитов Африки. В кн.: 493Карбонатиты, М.: Мир, 1969, с. 328-355. 
494Илупин И.П., Каминский Ф.В., Францессон Е.В. Геохимия кимберлитов. М.: Недра, 1978, 495352 c.

4963айцев А.Н., Вильямс С.Т., Волл Ф., Золотарев А.А. Эволюция химического состава 497минералов группы пирохлора из фоскоритов и карбонатитов из Хибинского щелочного 498массива//Геология рудных месторождений, 2012, т. 54, № 7, с. 503-515.

499Капустин Ю.Л. Минералогия карбонатитов. М.: Наука, 1971, 288 с.

500Ковальский В.В. Кимберлитовые породы Якутии и основные принципы их 501петрогенетической классификации. М.: Изд-во АН СССР, 1963, 184 с.

502Ковальский В.В., Никишов К.Н., Егоров О.С. Кимберлитовые и карбонатитовые 503образования восточного и юго-восточного склонов Анабарской антеклизы. М.: Наука, 5041969, 288 c.

505Костровицкий С.И. Геохимические особенности минералов из кимберлитов. 506Новосибирск: Наука, 1986, 263 с.

507Костровицкий С.И., Морикио Т., Серов И.В., Яковлев Д.А., Амиржанов А.А. Изотопно508геохимическая систематика кимберлитов Сибирской платформы. Геология и геофизика, 5092007, T. 48, № 3, с. 350-371.

510Лапин А.В. Взаимоотношения карбонатитов и кимберлитов и некоторые проблемы 511магмообразования. Известия АН СССР, серия геологическая, 1986, № 12, с. 36-46.

512Лапин А.В., Маршинцев В.К. Карбонатиты и кимберлитовые карбонатиты // Геология 513рудных месторождений, 1964, № 3, с. 28-42.

514Мальков Б.А. Карбонатитовые кимберлиты - новый тип алмазоносных пород. Докл. АН 515CССР, 1975, т. 221, № 5, с. 1170-1173.

516Маршинцев В.К. О находке бадделеита в кимберлитовых породах Якутии. В кн.: 517Геология, петрография и минералогия магматических образований северо-восточной 518части Сибирской платформы. М. Наука, 1970, с. 247-253.

519Маршинцев В.К. Карбонатитовые образования восточного склона Анабарского сводового 520поднятия. Якутск: Якутское книжное идательство, 1974, 120 с.

521Милашев В.А. Кимберлитовые провинции. Л.: Недра, 1974, 238 с. 
522Фролов А.А., Лапин А.В., Толстов А.В., Зинчук Н.Н., Белов С.В., Бурмистров А.А., 523Карбонатиты и кимберлиты (взаимоотношение, минерагения, прогноз). НИА-Природа 524M, 2005, 540 c.

525Харькив А.Д., Зинчук Н.Н., Крючков А.И. Геолого-генетические основы шлихо526минералогического метода поисков алмазных месторождений. М.: Недра, 1995, 349 с. 527Харькив А.Д. Кимберлитовые трубки, совмещенные с трубками, как самостоятельная 528фаза кимберлитового магматизма. ДАН СССР, т. 224, 1975, № 1, с.190-193.

529Харькив А.Д., Зинчук Н.Н., Зуев В.М. История алмаза. М.: Издательство «Недра», 1997, 530601 c.

531Харькив А.Д., Зинчук Н.Н., Крючков А.И. Коренные месторождения алмазов Мира. М.: 532Издательство «Недра», 1998, 556 с.

533Чернышева Е.А., Костровицкий С. И. О природе карбонатитовых брекчий восточного 534склона Анабарской антеклизы. - ДАН СССР, т. 257, 1981, № 5, с. С. 1211-1213.

535Чернышева Е.А., Костровицкий С.И. Оливиновые мелилититы кимберлитовых и 536карбонатитовых формаций в дайках и диатремах Восточной Сибири. Геохимия, 1998, № 53712, с. $1217-1225$.

538Agashev, A. M., Pokhilenko, N. P., Takazawa, E. J., McDonald, A., Vavilov, M. A., Watanabe, 539T. \& Sobolev, N. V. Primary melting sequence of a deep (4250 km) lithospheric mantle as 540recorded in the geochemistry of kimberlite-carbonatite assemblages, Snap Lake dyke system, 541Canada. Chemical Geology, v. 255, 2008, p. 317-328.

542Barton E.S., Brakhfogel F.F., Williams I.S. U-Pb zircon age for carbonate and alkali-picrite 543pipes, Orto-Yarga field (Yakutia). Extended Abstracts of 6 IKC, Novosibirsk, 1995, p.37.

544Bell Keith. Carbonatites: Genesis and Evolution, London, Unwin Hyman, 1989.

545Beyer, C., Berndt, J., Tappe, S., Klemme, S. Trace element partitioning between perovskite and 546kimberlite to carbonatite melt: new experimental constraints. Chemical Geology, v. 353, 2013, 547p. 132-139.

548Bailey D.K. Carbonatite magmas. Journal Geological Society, London, 150. 1993, pp. 637-651. 549Boctor N.Z., Boyd F.R. Oxide minerals in a layered kimberlite-carbonatite sill from 550Benfontein, South Africa, Contrib. Mineral. Petrol, v.76, 1981, p. 253-259. 
551Dalton, J. A. \& Presnall, D. C. The continuum of primary carbonatitic-kimberlitic melt 552compositions in equilibrium with lherzolite: data from the system CaO-MgO-Al2O3-SiO2553CO2 at 6GPa. Journal of Petrology, v. 39, 1998, p. 1953-1964.

554Dawson J.B. \& Hawthorne J.B. Magmatic sedimentation and carbonatic differentiation in 555kimberlite sills at Benfontein, South Africa. J. Geol. Soc. Lond, v. 129, 1973, p. 61-85.

556Eckermann H. A comparison of Swedish, African and Russian kimberlites. In: Ultramafic and 557related rocks, New York, 1967, p. 302-312.

558Edgar, A. D., Arima, M., Baldwin, D. K., Bell, D. R., Shee, S. R., Skinner, E. M. W. \& Walker, 559E. C. High-pressure-high temperature melting experiments on SiO2-poor aphanitic kimberlite 560from Wesselton mine, Kimberley, South Africa. American Mineralogistv v. 73, 1988, p. 524561533.

562Edgar, A. D. \& Charbonneau, H. E. Melting experiments on a SiO2-poor, CaO-rich aphanitic 563kimberlite from 5-10 GPa and their bearing on source of kimberlite magmas. American 564Mineralogist 78, 1993, 132-142.

565Gaspar J.C. \& Wyllie P.J. The alleged kimberlite-carbonatite relationship - evidence from 566ilmenite and spinel from Premier and Wesselton Mines and the Benfontein Sill, South-Africa. 567Contrib Mineral Petrol, 85(2), 1984, 133-140

568Griffin, W.L., Ryan, C.G., Kaminsky, F.V., O’Reilly, S.Y., Natapov, L.M., Win, T.T., Kinny, 569P.D., Ilupin, I.P. The Siberian lithosphere traverse: mantle terranes and the assembly of the 570Siberian Craton. Tectonophysics, v. 310, 1999, p. 1-35.

571Girnis, A.V., Bulatov,V. K. \& Brey, G. P. Transition from kimberlite to carbonatite melt under 572mantle parameters: an experimental study, Petrology, v. 13, 2005, p. 1-15.

573Gudfinnsson, G. H. \& Presnall, D. C. Continuous gradation among primary carbonatitic, 574kimberlitic, melilititic, basaltic, picritic, and komatiitic melts in equilibrium with garnet 575lherzolite at 3-8GPa. Journal of Petrology, v. 46, 2005, p. 1645-1659.

576Jones A.P., Carmody L., Genge M. Carbonate Melts and Carbonatites. Reviews in Mineralogy 577\& Geochemistry, v. 75, 2013, p. 289-322.

578Jacobsen S.B. \& Wasserburg G.J. Sm-Nd evolution of chondrites and achondrites. Earth and 579Planetary Science Letters, v. 67, 1984, p. 137-150.

580Kamenetsky V.S., Yaxley G.M. Carbonate-silicate liquid immiscibility in the mantle propels 581kimberlite magma ascent. Geochemica et Cosmochemica Acta, v. 158, 2015, p. 48-56. 
582Kopylova, M.G., Matveev, S., Raudsepp, M. Searching for parental kimberlite melt. 583Geochimica et Cosmochimica Acta, v. 71, 2007, p. 3616-3629.

584Mitchell R.H. The alleged kimberlite-carbonatite relationship: additional contrary 585mineralogical evidence. Amer. J. Sci. v. 279, 1979, p. 570-589.

586Mitchell R.H. Kimberlites: mineralogy, geochemistry and petrology. New York, Plenum Press, 5871986, $442 \mathrm{p}$.

588Mitchell R.H., Carbonatites and carbonatites and carbonatites. Canadian Mineralogist, v. 43(6), 5892007, p. 2049-2068.

590Pin C. \& Zalduegui J.F.S. Sequential separation of light rare-earth elements, thorium and 591uranium by miniaturized extraction chromatography: Application to isotopic analyses of 592silicate rocks. Analyt. Chim. Acta, v. 339, 1997, p. 79-89.

593Pivin M., Debaille V., Mattielli N., \& Demaiffe D. Nd-Hf Isotope systematics of megacrysts 594from the Mbuji-Mayi kimberlites, D. R. Congo: Evidence for a metasomatic origin related to 595kimberlite interaction with the cratonic lithospheric mantle. Proceedings of 10th International 596Kimberlite Conference, V. 1, Special Issue of the Journal of the Geological Society of India, 5972013, p. 123-136.

598Price S.E., Russell J.K., Kopylova M.G. Primitive magma from the Jericho pipe, N.W.T., 599Canada: Constraints on primary kimberlite melt chemistry. J Petrol, v.41 (6), 2000, p. 789-808.

600Rass, I.T. Geochemical features of carbonatite indicative of the composition, evolution, and 601differentiation of their mantle magmas. Geochem. Int., 36, 1998, p. 107-116.

602Russell J. K., Porritt L.A., Lavallee Yan, Dingwell D.B. Kimberlite ascent by assimilation 603fuelled buoyancy. Nature, v.481, no. 19, 2012, p.352-356.

604Safonov O.G., Kamenetsky V. S., Perchuk L. L. Links between carbonatite and kimberlite 605melts in chloride carbonate-silicate systems: experiments and application to natural 606assemblages. J. Petrology, v. 52, 2011, p. 1307-1331.

607Scatena-Wachel D.E. \& Jones A.P. Primary baddeleyite ( $\mathrm{ZrO} 2)$ in kimberlite from Benfontein, 608South Africa. Mineral Magazine. v. 48, 1984, p. 257-261.

609Sharygin V.V., Sobolev N.V., Channer D.M.D. Oscillatory-zoned crystals of pyrochlore-group 610minerals from the Guaniamo kimberlites, Venezuela. Lithos, v. 112S, 2009, p. 976-985. 
611Shee, S. R. The petrogenesis of the Wesselton mine kimberlites, Kimberley, South Africa. 612Ph.D. Thesis, University of Cape Town, 1986.

613Smith C.B., Pb, Sr and Nd isotopic evidence for sources of African Cretaceous kimberlite 614Nature, v. 304, 1983, p. 51-54.

615Smith C.B., Haggerty S.E., Chatterjee B., Beard A., Townend R. Kimberlite, lamproite, 616ultramafic lamprophyre, and carbonatite relationships on the Dharwar Craton, India; an 617example from the Khaderpet pipe, a diamondiferous ultramafic with associated carbonatite 618intrusion. Volumes 182-183, 2013, p 102-113.

619Sun J., Liu C.-Z., Tappe S., Kostrovitsky S. I., Wu Fu-Yuan, Yakovlev D., Yang Yue-Heng, 620Yang Jin-Hui. Repeated kimberlite magmatism beneath Yakutia and its relationship to Siberian 621flood volcanism: insights from in situ U-Pb and Sr-Nd perovskite isotope analysis. Earth and 622Planetary Science Letters, v. 404, 2014, p, 283-295.

623Sun J., Tappe S., Kostrovitsky S.I., Liu C.-Z., Skuzovatov S.Yu., Wu F.-Y. Mantle sources of 624kimberlites through time: $\mathrm{A} \mathrm{U}-\mathrm{Pb}$ and $\mathrm{Lu}-\mathrm{Hf}$ isotope study of zircon megacrysts from the 625Siberian diamond fields. Chemical Geology, v. 479, 2018, p. 228-240.

626Tainton K.M. \& McKenzie D. The generation of kimberlites, lamproites, and their source 627rocks. J. Petrol., v.35, 1994, p. 787-817.

628Tappe S., Pearson G., Prelević D. Kimberlite, carbonatite, and potassic magmatism as part of 629the geochemical cycle. Chemical Geology. v. 353, 2013, p. 1-3. DOI:10.1002/chin.201349218

630Terry W. C., The occurrence of niobian zirconolite, pyrochlore and baddeleyite in the Kovdor 631carbonatite complex, Kola Peninsula, Russia. Mineralogical Magazine. V. 60, Issue 401, 1996, 632p. 639-646.

633Verwoerd W.J. South Africa carbonatites and their probable mode of origin. Ann. Univ. Van 634Stellenbosch, 41, SerA, 2, 1966, p. 116-233.

635Weiss, Y., Griffin,W. L., Bell D.R., Navon, O., High-Mg carbonatitic melts jn diamonds, 636kimberlites and the sub-continental lithosphere. EPSL, v. 309, 2009, p. 337-347.

637Whitney D.L., Evans B.W. Abbreviations for names of rock-forming minerals. American 638Mineralogist, Volume 95, 2010, pp. 185-187.

639Wyllie, P.J. \& Lee, W.J., Kimberlites, carbonatites, peridotites and silicate-carbonate liquid 640immiscibility explained in parts of the system $\mathrm{CaO}-(\mathrm{Na} 2 \mathrm{O}+\mathrm{K} 2 \mathrm{O})-(\mathrm{MgO}+\mathrm{FeO})-(\mathrm{SiO} 2+\mathrm{Al} 2 \mathrm{O} 3)-$ 641CO2. In: Proceedings of the 7th IKC, v.2, Cape Town, South Africa, 1999, p. 923-932. 


\section{Подписи к рисункам статьи Костровицкого С.И. и др.}

Рис. 1. Карта расположения кимберлитовых полей в Якутской провинции. Штриховыми линиями показаны три линейные зоны, к которым приурочены поля.

Рис. 2. Фотография образца карбонатитоподобной породы из дайки трубки Айхал.

Рис. 3. Микрофотографии в режиме СОМРО (BSE). а - обр. 05-480. Основная масса карбонатитоподобной породы из трубки Айхал. b - обр. 05-480. Основная масса карбонатитоподобной породы Phl-Dol состава из трубки Айхал. 1-3 - Ap; 4 - Dol; 5-6 - Phl. Составы минералов приведены в табл. 1s, 2s, 3s (supplementary). с - обр. 13-49. Зерна монацита в основной массе карбонатитоподобной породы, приуроченные к выделениям Cal. d - Обр. 05-480. Основная масса карбонатитоподобной породы. Сросток бадделеита с кристаллом флогопита. е - обр. 05-480. Основная масса карбонатита Srp-Phl-Dol состава с микрозернами пирохлора, пикроильменита и апатита. f - обр. 13-49. Включение зерна бетафита (из группы пирохлора) в кристалле Phl. Основная масса породы имеет Cal-PhlDol состав. h, g - Зерна пирохлора из тяжелой фракции карбонатитовых брекчий участка Номохтоох со множеством включений апатита разной ориентировки в разных доменах кристаллов (g - зерно № 57, h - зерно № 8).

Рис. 4. Графики состава кимберлитов и карбонатитов из трубки Айхал и Номохтоохского участка Староречинского поля (Табл. 1). Условные обозначения: 1 - кимберлиты из трубки Айхал; 2 -карбонатитоподобная порода из дайки трубки Айхал; 3 - кимберлитовые брекчии из трубки участка Номохтоох Староречинского поля; 4 - карбонатитовые брекчии из трубок участка Номохтоох Староречинского поля; 5 - средние составы кимберлитов из центра и северо-восточной части трубки Айхал по данным Илупина и др. (1978).

Заштрихованное поле - область значений состава для карбонатитовых брекчий по В.К. Маршинцеву (1974).

Рис. 5. Спайдер-диаграммы распределения некогерентных элементов для кимберлитов и карбонатитоподобной породы из трубки Айхал и из карбонатитовых брекчий участка Номохтоох Староречинского поля (Табл. 2). Подписи см. на Рис. 4. Заштрихованное поле область составов для алмазоносных кимберлитов ЯКП.

Рис. 6. График изотопных составов в координатах $\left.\left({ }^{87} \mathrm{Sr} /{ }^{86} \mathrm{Sr}\right)\right)_{0}-\varepsilon \mathrm{Nd}$ для кимберлитов и карбонатитоподобной породы из трубки Айхал и из карбонатитовых и кимберлитовых брекчий участка Номохтоох.

Рис. 1s. Обр. 05-480. Основная масса карбонатитоподобной породы из трубки Айхал.

Рис. 2s. Обр. 05-480. Основная масса карбонатитоподобной породы Phl-Dol состава из трубки Айхал. 1-3 - Ap; 4 - Dol; 5-6 - Phl. Составы минералов приведены в табл. 1s, 2s, 3s (supplementary).

Рис. 3s. Обр. 13-49. Зерна монацита в основной массе карбонатитоподобной породы, приуроченные к выделениям Cal.

Рис. 4s. Обр. 05-480. Обр. 05-480. Основная масса карбонатитоподобной породы. Сросток бадделеита с кристаллом флогопита.

Рис. 5s. Обр. 05-480. Основная масса карбонатита Srp-Phl-Dol состава с микрозернами пирохлора, пикроильменита и апатита. 
Pис. 6s. Обр. 13-49. Включение зерна бетафита (из группы пирохлора) в кристалле Phl. Основная масса породы имеет Cal-Phl-Dol состав.

Рис. 7s. Форма зерен минералов из тяжелой фракции карбонатитовых брекчий участка Номохтоох. Номера зерен соответствуют номерам зерен, состав которых показан в таблицах 12, 13, 14 . Бадделеит: зерна 1-3, 5-6; ряд 5, зерна 40-42; ряд 6, зерна 46-48, 50-52. Пирохлор: зерна 8-12, 14, 15; Ряд 4, зерна 30-34, 36-38. Циркон: зерно 13. Апатит: зерна 16-18, 24-26.

Рис. 8s. Графики REE-La/Yb, La/Nb, Pb/Се для кимберлитов и карбонатитоподобной породы из трубки Айхал и из карбонатитовых и кимберлитовых брекчий участка Номохтоох. 
Табл. 1. Химический состав кимберлитов и карбонатитоподобной породы из трубки Айхал и карбонатитовых брекчий из участка Номохтоох Староречинского поля.

\begin{tabular}{|c|c|c|c|c|c|c|c|c|c|c|c|c|}
\hline & 1 & 2 & 3 & 4 & 5 & 6 & 7 & 8 & 9 & 10 & 11 & 12 \\
\hline & $06-42$ & $\begin{array}{c}06- \\
76 \mathrm{kp}\end{array}$ & $\begin{array}{c}06- \\
76 \mathrm{mp}\end{array}$ & $\begin{array}{c}\text { 05-480 } \\
\text { дайка }\end{array}$ & $\begin{array}{c}\text { 05-480 } \\
\text { кб }\end{array}$ & $\begin{array}{l}\text { 13-49 } \\
\text { дайка }\end{array}$ & $\begin{array}{l}01- \\
361\end{array}$ & $\begin{array}{c}\text { Среднее } \\
\text { (17) }\end{array}$ & $\begin{array}{c}\text { Среднее } \\
\text { (9) }\end{array}$ & $\begin{array}{c}78- \\
1565\end{array}$ & $\begin{array}{c}78- \\
1558\end{array}$ & $90-67$ \\
\hline $\mathrm{SiO}_{2}$ & 26.72 & 29.11 & 25.89 & 13.64 & 33.17 & 10.72 & 25.58 & 26.41 & 17.02 & 13.64 & 7.89 & 25.1 \\
\hline $\mathrm{TiO}_{2}$ & 0.45 & 0.61 & 0.64 & 0.35 & 0.29 & 0.47 & 0.55 & 0.4 & 0.34 & 0.17 & 0.18 & 1.18 \\
\hline $\mathrm{Al}_{2} \mathrm{O}_{3}$ & 1.78 & 2.27 & 2.9 & 4.8 & 2.15 & 3.97 & 1.66 & 2.2 & 2.68 & 3.47 & 1.33 & 2.7 \\
\hline $\mathrm{Fe}_{2} \mathrm{O}_{3}$ & 2.75 & 5.72 & 3.81 & 2.96 & 3.65 & 2.65 & 4.5 & 3.32 & 2.68 & н/опр & н/опр & н/опр \\
\hline $\mathrm{FeO}$ & 0.89 & 1.91 & 1.32 & 1.03 & 1.57 & 1.0 & 1.53 & 1.1 & 1.24 & 7.88* & $13^{*}$ & 7.39* \\
\hline $\mathrm{MnO}$ & 0.06 & 0.03 & 0.04 & 0.09 & 0.05 & 0.04 & 0.07 & 0.07 & 0.07 & 0.88 & 1.04 & 0.19 \\
\hline $\mathrm{MgO}$ & 28.52 & 24.73 & 17.12 & 23.5 & 33.81 & 16.35 & 24.71 & 25.05 & 17 & 9.78 & 9.5 & 22.34 \\
\hline $\mathrm{CaO}$ & 14.69 & 12.38 & 22 & 19.16 & 5.52 & 28.14 & 17.3 & 16.92 & 24.45 & 28.38 & 28.14 & 14.55 \\
\hline $\mathrm{Na}_{2} \mathrm{O}$ & 0.23 & 0.22 & 0.2 & 0.2 & 0.21 & 0.35 & 0.18 & 0.13 & 0.12 & 1.2 & 0.28 & 0.06 \\
\hline $\mathrm{K}_{2} \mathrm{O}$ & 0.506 & 1.019 & 1.45 & 2.19 & 0.5 & 1.59 & 0.47 & 0.32 & 1.16 & 1.19 & 0.51 & 0.6 \\
\hline $\mathrm{H}_{2} \mathrm{O}$ & 11.28 & 11.83 & 9.03 & 3.36 & 12.8 & 2.49 & 9.28 & 9.24 & 5.07 & 1.66 & 2.24 & 12.02 \\
\hline $\mathrm{CO}_{2}$ & 11.14 & 8.32 & 15.46 & 25.65 & 5.99 & 28 & 13.34 & 13.72 & 27.4 & 28.16 & 30.8 & 12.78 \\
\hline $\mathrm{F}$ & 0.35 & 0.6 & 0.62 & 0.26 & 0.65 & н/опр & 0.24 & н/опр & н/опр & н/опр & н/опр & н/опр \\
\hline $\mathrm{P}_{2} \mathrm{O}_{5}$ & 0.67 & 0.95 & 0.63 & 0.53 & 0.46 & 1.02 & 0.93 & 0.43 & 0.31 & 1.83 & 3.55 & 0.42 \\
\hline $\mathrm{SO}_{3}$ & н/опр & н/опр & н/опр & н/опр & н/опр & 3.25 & н/опр & н/опр & н/опр & н/опр & н/опр & н/опр \\
\hline Total & $\begin{array}{l}100.0 \\
4\end{array}$ & 99.7 & $\begin{array}{l}101.1 \\
1\end{array}$ & 97.72 & 100.82 & 100.04 & $\begin{array}{l}100.3 \\
4\end{array}$ & 99.31 & 99.54 & 98.24 & 97.95 & 99.33 \\
\hline
\end{tabular}

1-9 - из трубки Айхал; 10-12 - из участка Номохтоох, из трубок: 10 - Токио, 11 - Прима, 12 Джо-северная; 1-7, 10-12 - данные авторов; 8-9 - усредненные данные из книги Илупина и др.,1978: 8 - центр трубки, 9 - СВ трубки, в скобках - число анализов; н/опр - содержание не определялось; * - общее железо в форме $\mathrm{FeO}$. 
Табл. 2. Микроэлементный состав кимберлитов и карбонатитоподобной породы из трубки Айхал и карбонатитовых брекчий из участка Номохтоох Староречинского поля, в г/т.

\begin{tabular}{|c|c|c|c|c|c|c|c|c|c|c|}
\hline & 1 & 2 & 3 & 4 & 5 & 6 & 7 & 8 & 9 & 10 \\
\hline $\begin{array}{l}\text { Эле- } \\
\text { мент }\end{array}$ & $06-42$ & $\begin{array}{c}06- \\
76 \mathrm{kp}\end{array}$ & $\begin{array}{c}06- \\
76 \mathrm{mp}\end{array}$ & 01-361 & $\begin{array}{c}\text { 05-480 } \\
\text { кб }\end{array}$ & $\begin{array}{c}05-480 \\
\text { дайка }\end{array}$ & $\begin{array}{l}13-49 \\
\text { дайка }\end{array}$ & $\begin{array}{c}78- \\
1565\end{array}$ & $\begin{array}{c}78- \\
1558\end{array}$ & $90-67$ \\
\hline Sc & 10.9 & 19 & 10,2 & н/опр & 11,8 & 22 & 24 & н/опр & н/опр & н/опр \\
\hline $\mathrm{V}$ & 54 & 68 & 79 & 62 & 98 & 54 & 79 & 32 & 50 & 89 \\
\hline $\mathrm{Cr}$ & 1144 & 2235 & 1052 & 843 & 944 & 691 & 1013 & 35 & 32 & $\begin{array}{l}662 \\
\end{array}$ \\
\hline Co & 32 & 100 & 61 & 62 & 68 & 45 & 25 & 10 & 19 & 60 \\
\hline $\mathrm{Ni}$ & $\begin{array}{l}797 \\
\end{array}$ & 1411 & 1046 & 1363 & 1232 & 1431 & 366 & 12 & 63 & 705 \\
\hline $\mathrm{Cu}$ & 4.16 & 43 & 418 & 11 & 136 & 112 & 94 & 8 & 7 & 62 \\
\hline $\mathrm{Zn}$ & 17 & 28 & 24 & 42 & 19 & 43 & 7.5 & н/опр & н/опр & 80 \\
\hline $\mathrm{Rb}$ & 27 & 54 & 71 & 24 & 27 & 113 & 118 & 27 & 14 & 31 \\
\hline Sr & 502 & 583 & 920 & $\begin{array}{l}618 \\
\end{array}$ & 152 & 1016 & 528 & 2104 & 4679 & 624 \\
\hline $\mathrm{Y}$ & $\begin{array}{ll}14.8 \\
\end{array}$ & 16 & 16 & 18 & 15 & 22 & 44 & 108 & 85 & 57 \\
\hline $\mathrm{Zr}$ & 185 & 316 & 174 & 143 & 122 & 121 & 148 & 235 & 240 & 118 \\
\hline $\mathrm{Nb}$ & 202 & 290 & 191 & 263 & 153 & 531 & 423 & 1012 & 808 & 234 \\
\hline Cs & 0.25 & 0.39 & 0.97 & 0.3 & 0.36 & 0.64 & 1.85 & 2.1 & 1.1 & 0.59 \\
\hline $\mathrm{Ba}$ & 1079 & 1280 & 1060 & 936 & 604 & 8574 & 4370 & 1807 & 1591 & 580 \\
\hline $\mathrm{La}$ & 124 & 126 & 119 & 193 & 67 & 961 & 582 & 1929 & 3636 & 171 \\
\hline Ce & 229 & 241 & 209 & 325 & 135 & 1398 & 1016 & 3032 & 4832 & 271 \\
\hline $\operatorname{Pr}$ & 23 & 24 & 21 & 32 & 14.9 & 115 & 93 & 269 & 364 & 25 \\
\hline $\mathrm{Nd}$ & 79 & 84 & 74 & 110 & 56 & 326 & 285 & 1029 & 1187 & 81 \\
\hline $\mathrm{Sm}$ & 9.7 & 11.2 & 9.4 & 14 & 8.9 & 29 & 40 & 118 & 103 & 10.2 \\
\hline $\mathrm{Eu}$ & 2.34 & 2.98 & 2.47 & 3.5 & 2.40 & 5.2 & 10.4 & 27 & 23 & 2.61 \\
\hline Gd & 7.4 & 8.1 & $\begin{array}{l}7.1 \\
\end{array}$ & $\begin{array}{ll}0.8 \\
\end{array}$ & 7.7 & 25 & 39 & 88 & 90 & $\begin{array}{l}9.28 \\
\end{array}$ \\
\hline $\mathrm{Tb}$ & 0.83 & 0.87 & 0.82 & 1.1 & 0.94 & 1.09 & 3.34 & 7.8 & 7.0 & 1.19 \\
\hline Dy & 3.20 & 3.62 & 3.00 & 4.1 & 3.35 & 4.54 & 12.3 & 29 & 24 & 6.43 \\
\hline Но & 0.49 & 0.56 & 0.52 & 0.6 & 0.51 & 0.72 & 1.88 & 4.2 & 3.3 & 1.16 \\
\hline Er & 1.01 & 1.22 & 1.01 & 1.3 & 1.13 & 1.45 & 4.35 & 9.1 & 7.7 & 2.94 \\
\hline $\mathrm{Tm}$ & 0.12 & 0.14 & 0.14 & 0.1 & 0.13 & 0.17 & 0.47 & 0.9 & 0.8 & 0.38 \\
\hline $\mathrm{Yb}$ & $\begin{array}{l}0.73 \\
\end{array}$ & 0.80 & 0.81 & 0.8 & 0.88 & $\begin{array}{l}1.02 \\
\end{array}$ & 2.65 & 5.0 & 4.1 & 2.20 \\
\hline $\mathrm{Lu}$ & 0.094 & 0.13 & 0.12 & 0.1 & 0.12 & 0.13 & 0.34 & 0.6 & 0.5 & 0.26 \\
\hline $\mathrm{Hf}$ & 3.40 & 5.8 & 3.49 & 3.4 & 2.41 & 2.57 & 5.3 & 5.3 & 4.6 & 3.36 \\
\hline $\mathrm{Ta}$ & 8.4 & 13.4 & 7.9 & 9.2 & 4.77 & 8.2 & 24 & 25 & 50 & 5.62 \\
\hline $\mathrm{Pb}$ & 1.44 & 22 & 13.2 & 2.8 & 10.0 & 23 & 19 & 42 & 21 & 7.30 \\
\hline Th & 15 & 24 & 13.0 & 24.0 & 9.5 & 10.1 & 22 & 122 & 79 & 18.36 \\
\hline
\end{tabular}




\begin{tabular}{|c|r|r|r|r|r|r|r|r|r|r|}
\hline & & & & & & & & & & \\
\hline $\mathrm{U}$ & 2.71 & 4.23 & 3.82 & 5.5 & 1.66 & 5.5 & 6.0 & 20 & 45 & 2.78 \\
\hline $\mathrm{REE}$ & 482 & 504 & 448 & 696 & 299 & 2868 & 2090 & 6548 & 10282 & 585 \\
\hline $\mathrm{La} / \mathrm{Yb}$ & 170 & 158 & 147 & 241 & 76 & 942 & 220 & 386 & 887 & 78 \\
\hline $\mathrm{La} / \mathrm{Nb}$ & 0,61 & 0,43 & 0,62 & 0,73 & 0,44 & 1,81 & 1,38 & 1,91 & 4,5 & 0,73 \\
\hline $\mathrm{Nb} / \mathrm{Ta}$ & 24,05 & 21,64 & 24,18 & 28,59 & 32,08 & 64,76 & 17,63 & 40,48 & 16,16 & 41,64 \\
\hline $\mathrm{Zr} / \mathrm{Hf}$ & 54,41 & 54,48 & 49,86 & 42,06 & 50,62 & 47,08 & 27,92 & 44,34 & 52,17 & 35,12 \\
\hline $\mathrm{Pb} / \mathrm{Ce}$ & 0,05 & 0,22 & 0,22 & 0,05 & 0,15 & 0,51 & 0,76 & 4,2 & 1,11 & 0,12 \\
\hline
\end{tabular}

1-5 - кимберлит из трубки Айхал; 6-7 - карбонатитоподобная порода из дайки в трубке Айхал; 8-9 - карбонатит из трубок участка Номохтоох; 10 - кимберлит из трубки участка Номохтоох. 
Табл. 3. Изотопный Rb-Sr состав кимберлитов и карбонатитоподобной породы из трубки Айхал и карбонатитовых брекчий из участка Номохтоох Староречинского поля.

\begin{tabular}{|c|c|c|c|c|c|c|c|}
\hline № & Образец & Трубка & $\mathrm{Rb}$ & $\mathrm{Sr}$ & ${ }^{87} \mathrm{Sr} /{ }^{86} \mathrm{Sr}$ & ${ }^{87} \mathrm{Rb} /{ }^{86} \mathrm{Sr}$ & $\left({ }^{87} \mathrm{Sr} /{ }^{86} \mathrm{Sr}\right)_{\mathrm{T}}$ \\
\hline 1 & $01-361$ & Айхал & $\begin{array}{c}27.2 \\
7\end{array}$ & $\begin{array}{c}748 . \\
5\end{array}$ & $\begin{array}{c}0.704652 \pm 1 \\
4\end{array}$ & 0.1052 & 0.704113 \\
\hline 2 & $13-49$ & $-/ /-$ & $\begin{array}{c}117 . \\
1\end{array}$ & $\begin{array}{c}506 . \\
7\end{array}$ & $\begin{array}{c}0.709987 \pm 1 \\
8\end{array}$ & 0.6697 & 0.706555 \\
\hline 3 & $05-480$ & $-/ /-$ & $\begin{array}{c}105 . \\
5\end{array}$ & $\begin{array}{c}982 . \\
8\end{array}$ & $\begin{array}{c}0.709102 \pm 2 \\
0\end{array}$ & 0.3106 & 0.707510 \\
\hline 4 & $78-1565$ & Токио & $\begin{array}{c}25.6 \\
2733\end{array}$ & $\begin{array}{c}0.703644 \pm 1 \\
4\end{array}$ & 0.0271 & 0.703575 \\
\hline 5 & $90-67$ & Джо-сев & $\begin{array}{c}36.5 \\
1\end{array}$ & $\begin{array}{c}722 . \\
1\end{array}$ & $\begin{array}{c}0.703868 \pm 1 \\
3\end{array}$ & 0.1462 & 0.703494 \\
\hline 6 & $78-1610$ & Ан-41n & $\begin{array}{c}33.7 \\
9\end{array}$ & $\begin{array}{c}741 . \\
2\end{array}$ & $\begin{array}{c}0.704593 \pm 1 \\
3\end{array}$ & 0.1319 & 0.704255 \\
\hline
\end{tabular}

Данные изотопного состава для проб № 1, 4-6 приведены из статьи (Костровицкий и др.. 2007); изотопный состав для проб № 2, 3 - настоящая работа. Начальные изотопные характеристики Sr и Nd рассчитаны для проб из трубки Айхал (№ 1-3) на 360 млн лет. из участка Номохтоох - на 180 млн лет. 
Табл. 4. Изотопный Sm-Nd состав кимберлитов и карбонатитоподобной породы из трубки Айхал и карбонатитовых брекчий из участка Номохтоох Староречинского поля.

\begin{tabular}{|c|c|c|c|c|c|c|c|}
\hline № & Образец & Трубка & $\begin{array}{c}\text { Sm } \\
(\mathrm{ppm})\end{array}$ & $\begin{array}{c}\mathrm{Nd} \\
(\mathrm{ppm})\end{array}$ & $\begin{array}{c}{ }^{143} \mathrm{Nd} / /^{144} \mathrm{Nd} \\
( \pm 2 \sigma)\end{array}$ & ${ }^{147} \mathrm{Sm} /{ }^{144} \mathrm{Nd}$ & $\varepsilon \mathrm{Nd}_{(\mathrm{T})}$ \\
\hline 1 & $01-361$ & Айхал & 11.8 & 114.2 & $0.512540 \pm 14$ & 0.06243 & 4.3 \\
\hline 2 & $13-49$ & $-/ /-$ & 41.9 & 240 & $0.512633 \pm 06$ & 0.0942 & 4.6 \\
\hline 3 & $05-480$ & $-/ /-$ & 30.5 & 220 & $0.512562 \pm 05$ & 0.0749 & 4.1 \\
\hline 4 & $78-1565$ & Токио & 104.9 & 913.2 & $0.512663 \pm 14$ & 0.0695 & 3.4 \\
\hline 5 & $90-67$ & Джо-сев & 10.2 & 82.7 & $0.512687 \pm 14$ & 0.0747 & 3.8 \\
\hline 6 & $78-1610$ & Ан-41n & 13.5 & 109.4 & $0.512688 \pm 14$ & 0.0745 & 3.8 \\
\hline
\end{tabular}

Данные изотопного состава для проб № 1, 4-6 приведены из статьи (Костровицкий и др., 2007); изотопный состав для проб № 2, 3 - настоящая работа. Начальные изотопные характеристики Nd рассчитаны для проб из трубки Айхал (№ 1-3) на 360 млн лет. из участка Номохтоох - на 180 млн лет. Расчет $\varepsilon \mathrm{Nd}_{(\mathrm{T})}$ производился с использованием современных значений в хондрите ${ }^{147} \mathrm{Sm} /{ }^{144} \mathrm{Nd}-$ 0.1967 и ${ }^{143} \mathrm{Nd} /{ }^{144} \mathrm{Nd}-0.512638$ (Jacobsen, Wasserburg, 1984). 
Табл. 5. Состав микрозерен пирохлора и бетафита из основной массы жильного кимберлита (обр. 05-480).

\begin{tabular}{|c|c|c|c|c|c|}
\hline & 1 & 2 & 3 & 4 & 5 \\
\hline № & im05-1 & im05-2 & im1-1 & im1-2 & im1-3 \\
\hline $\mathrm{SiO}_{2}$ & - & - & 4.24 & 4.36 & 4.05 \\
\hline $\mathrm{TiO}_{2}$ & 1.2 & 1.1 & 14.22 & 13.76 & 13.62 \\
\hline $\mathrm{Al}_{2} \mathrm{O}_{3}$ & - & - & 0.59 & 0.63 & 0.67 \\
\hline $\mathrm{FeO}$ & 0.84 & 0.87 & 3.57 & 3.64 & 3.70 \\
\hline $\mathrm{MgO}$ & 0.7 & 1.7 & 10.82 & 10.95 & 10.99 \\
\hline $\mathrm{CaO}$ & 20.8 & 20.7 & 10.49 & 11.30 & 11.47 \\
\hline $\mathrm{Na}_{2} \mathrm{O}$ & 6.7 & 6.2 & 0.23 & 0.20 & 0.26 \\
\hline $\mathrm{P}_{2} \mathrm{O}_{5}$ & 0.07 & 0.06 & 0.44 & 0.52 & 0.55 \\
\hline $\mathrm{F}$ & 0.26 & 0.23 & 0.43 & 0.25 & 0.23 \\
\hline $\mathrm{Nb}_{2} \mathrm{O}_{5}$ & 58.34 & 57.78 & 20.05 & 20.39 & 20.25 \\
\hline $\mathrm{ZrO}_{2}$ & 1.55 & 1.65 & 0.67 & 0.71 & 0.62 \\
\hline $\mathrm{La}_{2} \mathrm{O}_{3}$ & 0.62 & 0.95 & 1.42 & 1.45 & 1.23 \\
\hline $\mathrm{Ce}_{2} \mathrm{O}_{3}$ & 3.70 & 4.11 & 7.80 & 7.49 & 7.15 \\
\hline $\mathrm{Nd}_{2} \mathrm{O}_{3}$ & 0.8 & 0.45 & 4.61 & 4.59 & 4.57 \\
\hline $\mathrm{Pr}_{2} \mathrm{O}_{3}$ & 0.24 & 0.36 & 1.35 & 1.24 & 1.30 \\
\hline $\mathrm{Y}_{2} \mathrm{O}_{3}$ & $<0.1$ & $<0.1$ & 0.89 & 0.89 & 0.63 \\
\hline $\mathrm{ThO}_{2}$ & 0.33 & 0.21 & 0.54 & 0.63 & 0.56 \\
\hline $\mathrm{SO}_{3}$ & 0.11 & 0.14 & 0.49 & 0.43 & 0.45 \\
\hline Total & 93.29 & 93.69 & 82.92 & 83.83 & 82.65 \\
\hline
\end{tabular}

Зерна пирохлора: 1-2 из обр. 05-480; зерна бетафита размером <5 мкм: 3-5 - из обр. 13-49. 
Табл. 6. Состав макрокрист пирохлора из карбонатитовых брекчий участка Номохтоох Староречинского поля.

\begin{tabular}{|c|c|c|c|c|c|c|c|c|c|c|c|c|c|}
\hline № & $\mathrm{TiO}_{2}$ & $\mathrm{FeO}$ & $\mathrm{CaO}$ & $\mathrm{Na}_{2} \mathrm{O}$ & $\mathrm{F}$ & $\mathrm{SrO}$ & $\mathrm{Nb}_{2} \mathrm{O}_{5}$ & $\mathrm{La}_{2} \mathrm{O}_{3}$ & $\mathrm{Ce}_{2} \mathrm{O}_{3}$ & $\mathrm{Nd}_{2} \mathrm{O}_{3}$ & $\overline{\mathrm{Pr}_{2} \mathrm{O}_{3}}$ & $\mathrm{ThO}_{2}$ & Total \\
\hline r2-z7-1 & 0.87 & $<0.05$ & $\begin{array}{c}12.5 \\
5\end{array}$ & 9.86 & 2.6 & 3.68 & 68.42 & 0.72 & 1.42 & 0.28 & $<0.1$ & $<0.1$ & 100.4 \\
\hline r2-z8-1 & 1.38 & $<0.05$ & 11.27 & 9.74 & 2.46 & 4.76 & 66.79 & 1.5 & 2.15 & 0.31 & $<0.1$ & $<0.1$ & 100.36 \\
\hline r2-z9-1 & 0.96 & $<0.05$ & $\begin{array}{c}10.9 \\
2 \\
\end{array}$ & 9.93 & 2.42 & 4.41 & 67.08 & 1.29 & 2.51 & 0.5 & 0.2 & 0.14 & 100.36 \\
\hline r2-z10-1 & 1.45 & 0.1 & $\begin{array}{c}16.2 \\
3\end{array}$ & 8.87 & 2.37 & 0.69 & 69.86 & 0.07 & 0.36 & $<0.1$ & $<0.1$ & $<0.1$ & 100.00 \\
\hline r2-z-11-1 & 0.77 & 0.07 & 11.47 & 9.69 & 2.53 & 3.89 & 67.77 & 1.07 & 2.3 & 0.38 & $<0.1$ & $<0.1$ & 99.94 \\
\hline r2-z12-1 & 1.43 & 0.14 & $\begin{array}{c}16.1 \\
8\end{array}$ & 8.94 & 2.61 & 0.77 & 69.58 & 0.12 & 0.74 & 0.15 & $<0.1$ & $<0.1$ & 100.66 \\
\hline r2-z14-1 & 1.06 & 0.11 & $\begin{array}{c}15.7 \\
5\end{array}$ & 9.17 & 2.31 & 0.92 & 69 & 0.36 & 0.49 & 0.13 & $<0.1$ & 0.63 & 99.93 \\
\hline r2-z15-1 & 0.84 & $<0.05$ & 11.66 & 9.78 & 2.44 & 3.51 & 67.62 & 1.13 & 2.49 & 0.42 & 0.18 & $<0.1$ & 100.07 \\
\hline r4-z30-1 & 1.33 & 0.05 & $\begin{array}{c}16.0 \\
3\end{array}$ & 8.99 & 2.52 & 1.08 & 69.45 & $<0.1$ & 0.42 & 0.14 & $<0.1$ & 0.24 & 100.25 \\
\hline r4-z31-1 & 0.77 & 0.09 & $\begin{array}{c}13.3 \\
6 \\
\end{array}$ & 9.67 & 2.59 & 3.01 & 67.62 & 0.89 & 1.44 & 0.27 & $<0.1$ & $<0.1$ & 99.71 \\
\hline r4-z32-1 & 0.67 & $<0.05$ & 11.07 & 9.85 & 2.57 & 5.08 & 67.55 & 1.11 & 2 & 0.16 & 0.11 & $<0.1$ & 100.17 \\
\hline r4-z33-1 & 0.91 & $<0.05$ & $\begin{array}{c}10.5 \\
5 \\
\end{array}$ & 9.95 & 2.61 & 4.42 & 67.06 & 1.45 & 2.55 & 0.45 & 0.25 & 0.13 & 100.13 \\
\hline r4-z34-1 & 1.03 & 0.08 & $\begin{array}{c}10.7 \\
2 \\
\end{array}$ & 9.78 & 2.63 & 5.75 & 65.89 & 1.25 & 2.31 & 0.29 & 0.19 & $<0.1$ & 99.92 \\
\hline r4-z35-1 & 0.6 & $<0.05$ & 10.6 & 9.89 & 2.71 & 4.84 & 67.72 & 1.39 & 1.95 & 0.26 & $<0.1$ & 0.2 & 100.19 \\
\hline r4-z36-1 & 0.85 & 0.13 & 15 & 9.32 & 2.56 & 1.41 & 69.19 & 0.31 & 0.92 & 0.24 & $<0.1$ & $<0.1$ & 99.93 \\
\hline r4-z37-1 & 1.01 & 0.12 & $\begin{array}{c}12.3 \\
1 \\
\end{array}$ & 9.34 & 2.55 & 3.14 & 68.58 & 1.03 & 1.89 & 0.25 & 0.25 & $<0.1$ & 100.47 \\
\hline r4-z38-1 & 0.76 & 0.1 & $\begin{array}{c}14.4 \\
1\end{array}$ & 9.4 & 2.73 & 2.03 & 69.55 & 0.48 & 0.99 & 0.07 & $<0.1$ & 0.18 & 100.7 \\
\hline
\end{tabular}

Пробы из трубок: 7-15 - Джо-северная (обр. кимберлита № 90-63). 30-38 - Джо-южная. (обр. карбонатита №90-62). $\mathrm{ZrO}_{2}$ как правило <0.06; в одном зерне $0.14 \%$; $\mathrm{HfO}_{2}$. как правило $<0.1 \%$; в двух зернах 0.11 . $0.16 \%$. 


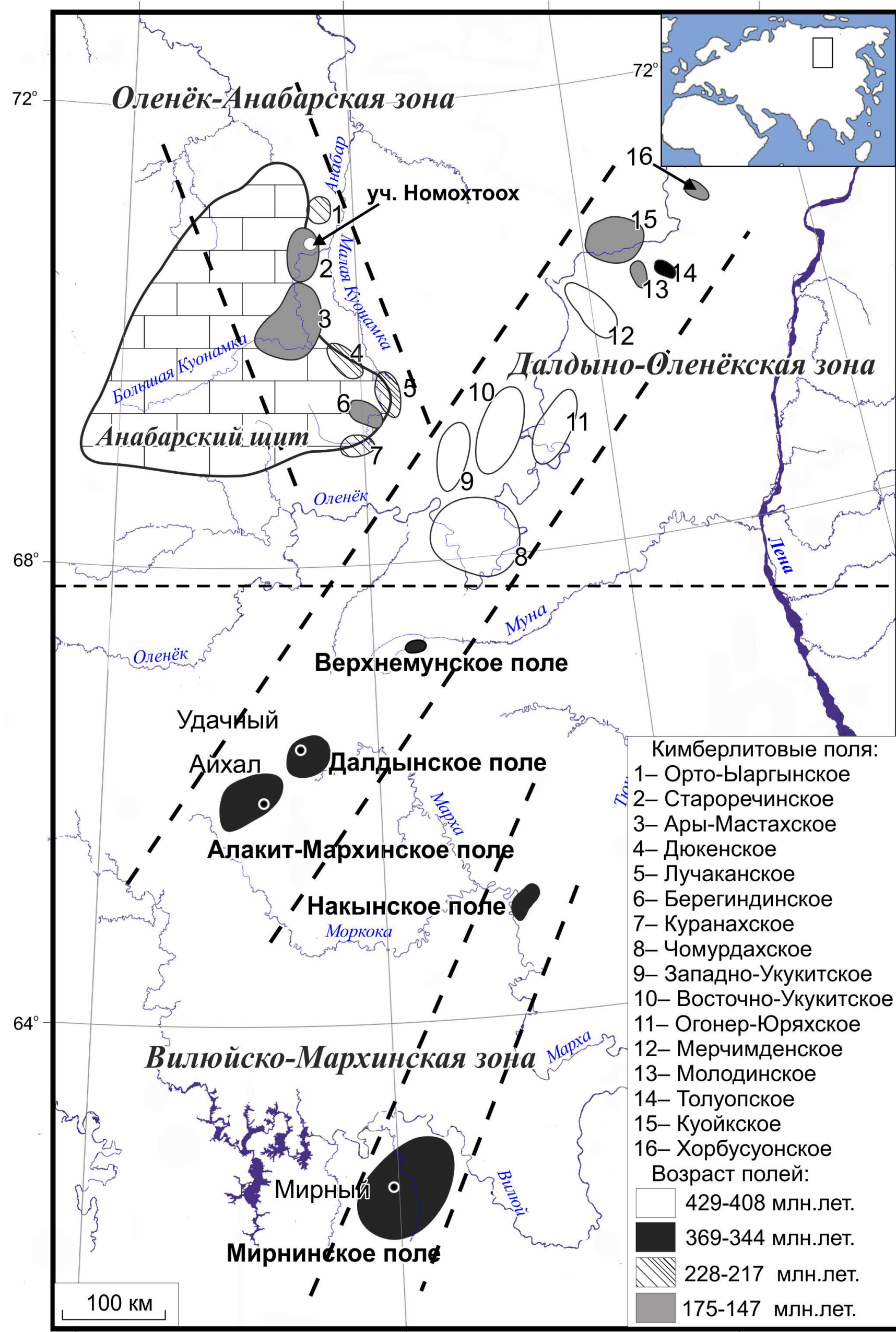




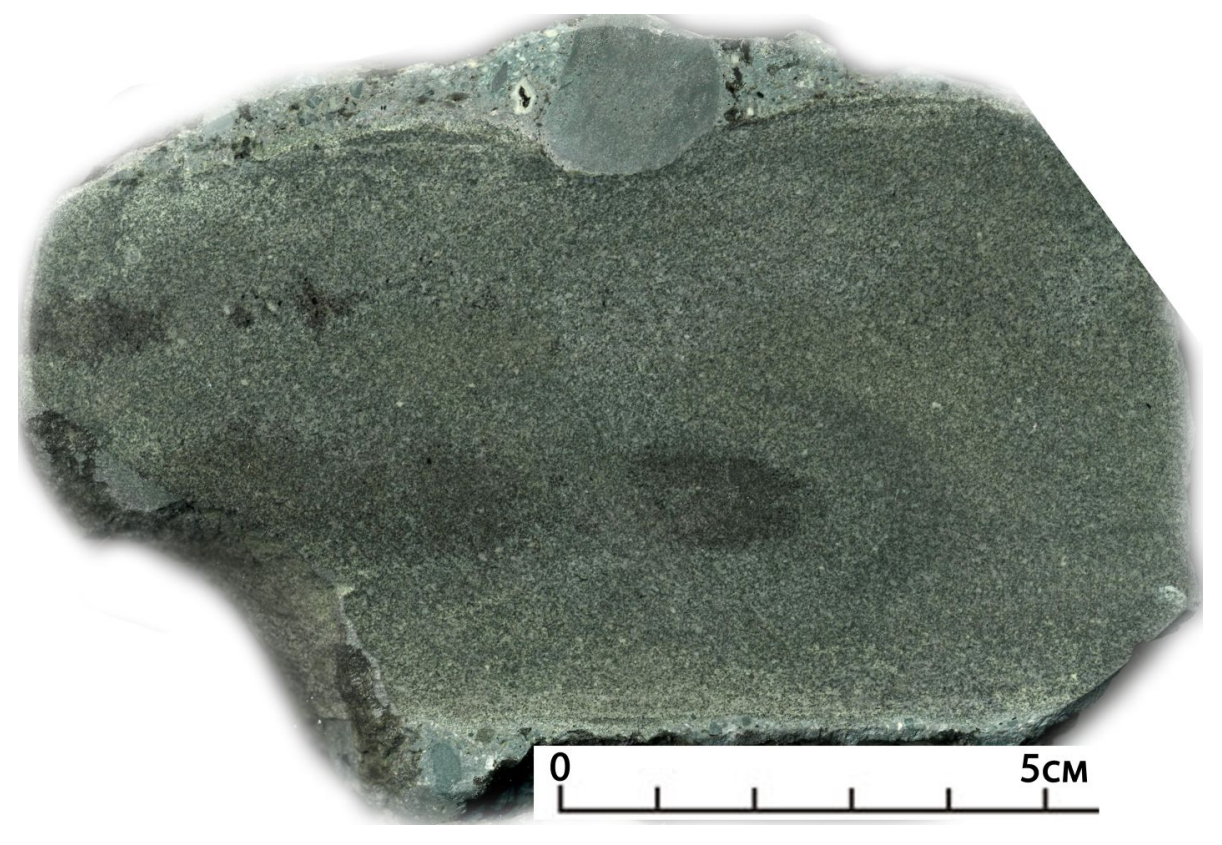



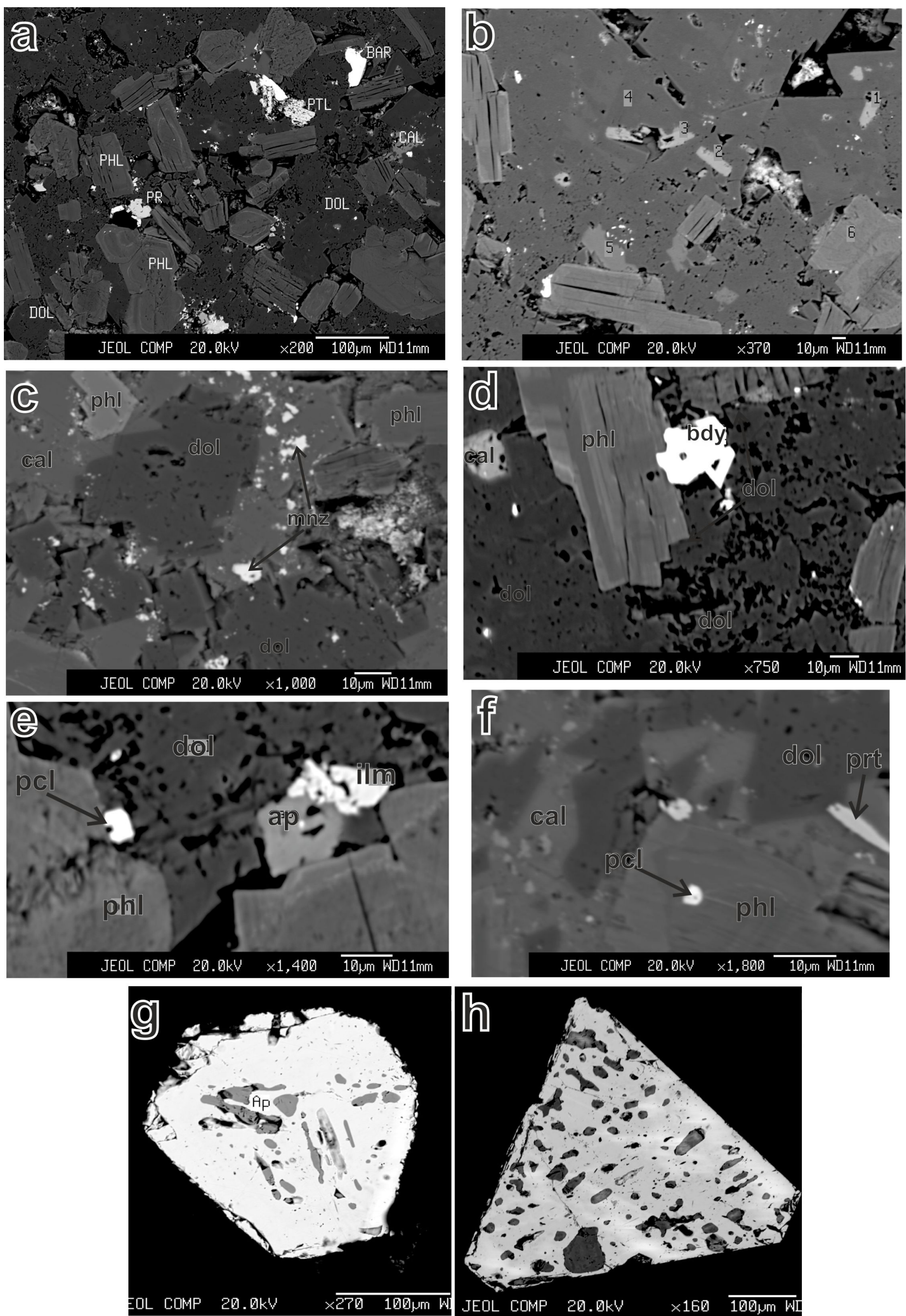

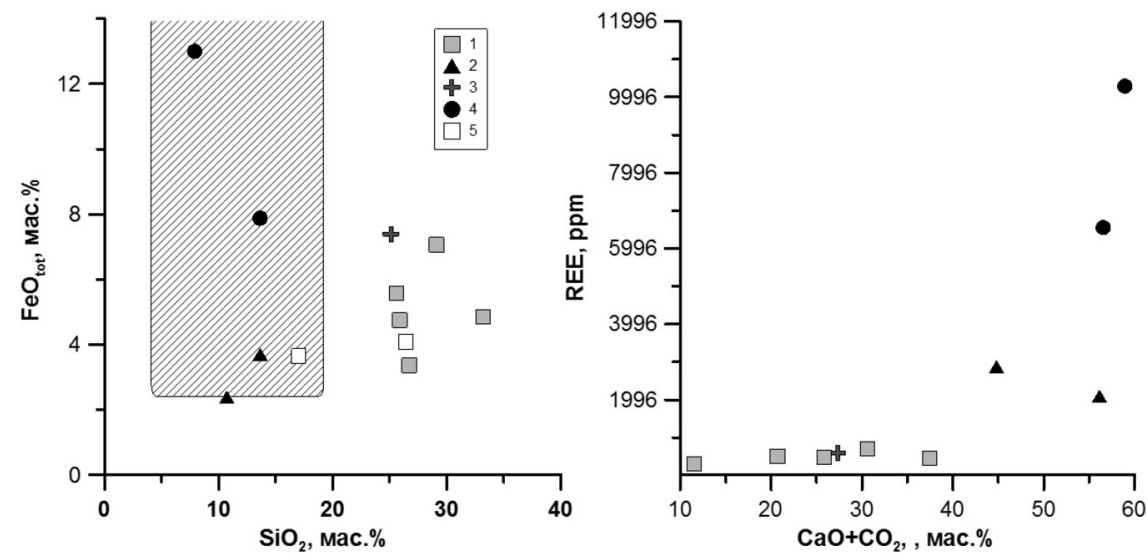


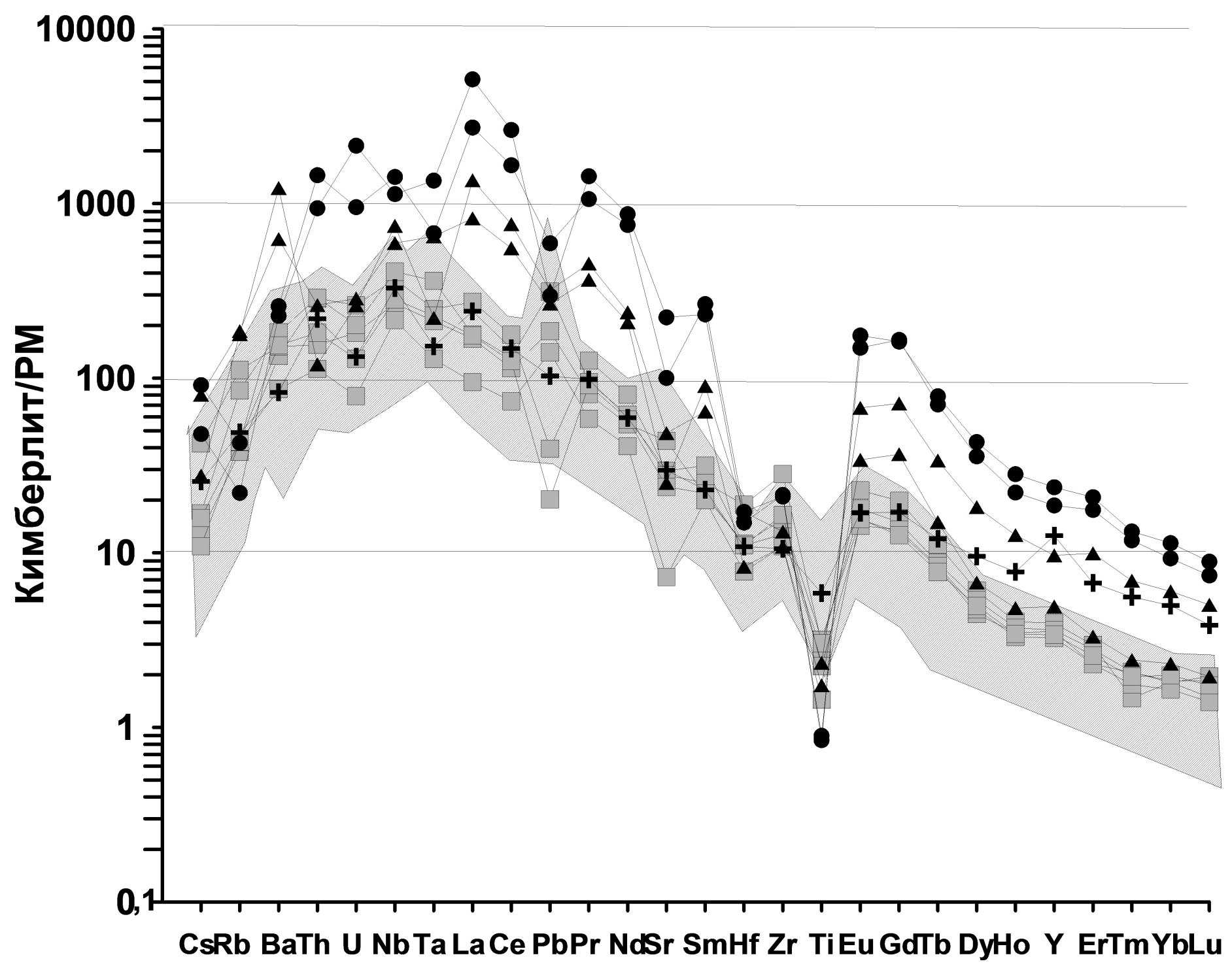




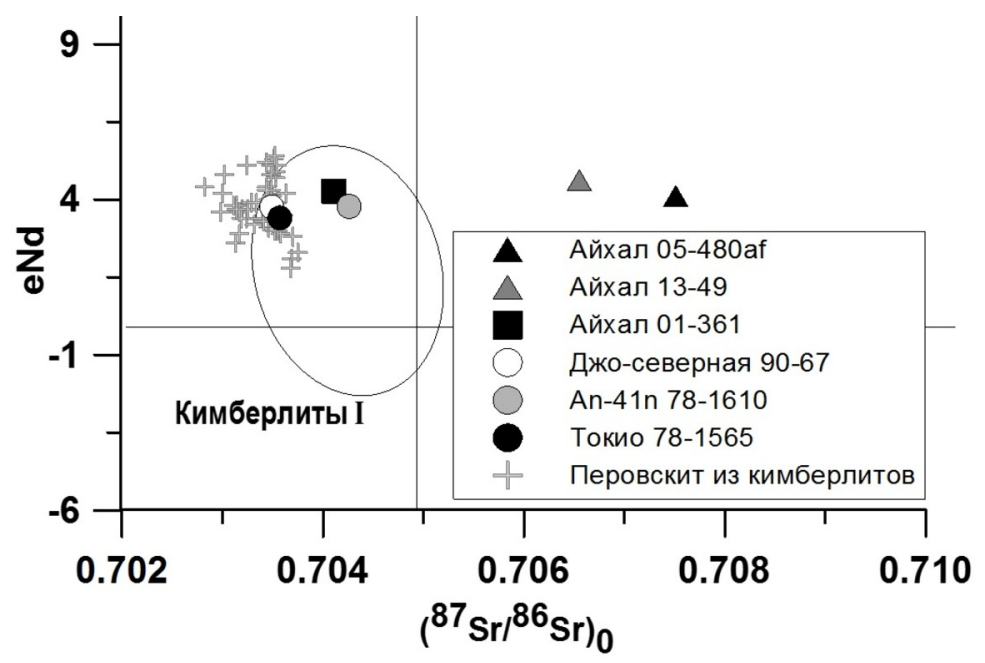

